University of Pennsylvania Carey Law School

Penn Carey Law: Legal Scholarship Repository

Faculty Scholarship at Penn Carey Law

8-11-2022

\title{
Are All Risks Created Equal? Rethinking the Distinction Between Legal and Business Risk in Corporate Law
}

Adi Libson

Bar Ilan University Faculty of Law

Gideon Parchomovsky

University of Pennsylvania Carey Law School

Follow this and additional works at: https://scholarship.law.upenn.edu/faculty_scholarship

Part of the Business Administration, Management, and Operations Commons, Business Law, Public Responsibility, and Ethics Commons, Business Organizations Law Commons, Corporate Finance Commons, Finance and Financial Management Commons, and the Law and Economics Commons

\section{Recommended Citation}

102 B.U. L. Rev. 1601 (2022).

This Article is brought to you for free and open access by Penn Carey Law: Legal Scholarship Repository. It has been accepted for inclusion in Faculty Scholarship at Penn Carey Law by an authorized administrator of Penn Carey Law: Legal Scholarship Repository. For more information, please contact PennlawIR@law.upenn.edu. 


\title{
ARE ALL RISKS CREATED EQUAL? RETHINKING THE DISTINCTION BETWEEN LEGAL AND BUSINESS RISK IN CORPORATE LAW
}

\author{
AdI LIBSON* \& GIDEON PARCHOMOVSKY**
}

\begin{abstract}
Should corporate legal risk be treated similarly to corporate business risk? Currently, the law draws a clear-cut distinction between the two sources of risk, permitting the latter and banning the former. As a result, fiduciaries are shielded from personal liability in the case of business risk and are entirely exposed to civil and criminal liability that arises from legal risk-taking. As corporate law theorists have underscored, the differential treatment of business and legal risk is highly problematic from the perspective of firms and shareholders. To begin with, legal risk cannot be completely averted or eliminated. More importantly, decisions involving negligible levels of legal risk might yield significant profits for firms. Thus, the outright ban on legal risktaking harms shareholders, who would have favored a more nuanced regime to optimize legal risk.

In this Article we make two novel contributions to corporate law scholarship, one descriptive and one normative. Descriptively, we offer a novel justification for the differential treatment of business and legal risk. We argue that because board members are exposed to personal liability for losses resulting from legal risk, they will veto all policies and decisions implicating legal risk, minimal though they may be. Aware of this disposition, managers - whose compensation is often tied to performance and who are therefore more risk-seeking-will prefer not to raise policies and decisions that implicate legal risk to board discussion. This preference, however, works to the detriment of shareholders who are deprived of the protective mechanism of board overview with respect to legal risk. Legal risks, therefore, largely escape board scrutiny. While the
\end{abstract}

\footnotetext{
* Assistant Professor, Bar-Ilan University Law Faculty.

** Robert G. Fuller, Jr. Professor of Law, University of Pennsylvania Carey Law School, and Wachtell, Lipton, Rosen \& Katz Professor of Corporate Law, Hebrew University School of Law. We would like to thank Michal Agmon-Gonen, Yifat Aran, Haled Cabub, Asaf Eckstein, Yuval Feldman, Jesse Fried, Assaf Hamdani, Sharon Hannes, Genvieve Helleringer, Kobi Kastiel, Hajin Kim, Donald Langevoort, Amir Licht, Barak Or, Elizabeth Pollman, Ruth Ronen, Roy Shapira, Holger Spamann, Alex Stein, Roberto Tallarita, Simone Tang, and participants at both the IDC Corporate Law Conference and the Institute for Advanced Studies Workshop. We thank Jeries Elias, Duncan Hall, Nicolas Harris, Nethanel Lousky, and Shelley Robinson for excellent research assistance.
} 
justification we advance has stronger explanatory power than prior justifications, it leaves open the possibility that the law may be redesigned in a more nuanced and desirable way. This rationale leads to the normative contribution of the Article. Consistent with the modern philosophy toward risk that maintains that all risks can be managed, we propose that legal risks be divided into two categories of severity: (1) risks involving criminal prohibitions and (2) risks pertaining to noncriminal norms. Each category should then be further broken down into three classes of risk based on probability of occurrence: remote, reasonable, and probable risk. Combining our two criteria generates six classes of legal risks, for each of which we develop a unique liability regime. The framework that we advance will allow corporate executives and directors to address low and reasonable levels of legal risk in a responsible way that will benefit shareholders without eroding respect for law and morality. 


\section{CONTENTS}

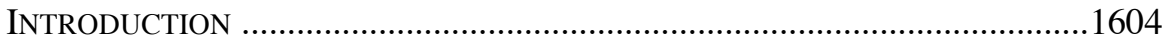

I. The Distinction BETwEen Business RISK AND LEGAL RISK.........1609

II. JUSTIFYING THE DisTINCTION 1614

A. The Different Nature of Business Risk and Legal Risk...............1614

B. The Epistemic Justification for the Distinction ..........................1617

C. The Expressive Justification .......................................................1620

D. The Greater Risk Legal Risks Impose on Long-Term

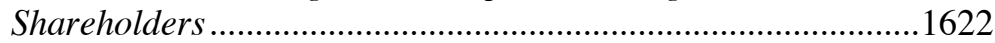

III. A NOVEL JUSTIFICATION FOR THE DISTINCTION: LACK OF EFFECTIVE OVERSIGHT ON LEGAL RISKS ..........................................1624

IV. A NEW FRAMEWORK FOR EVALUATING LEGAL RISK .......................1634

A. Criminal Violations v. Regulatory Infractions ..........................1635

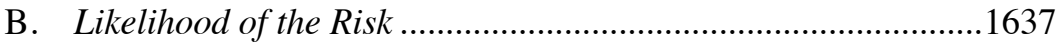

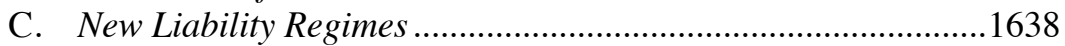

1. Remote Administrative Risk ..............................................1638

2. Remote Criminal Risk .......................................................1640

3. Reasonable Administrative Risk .........................................1642

4. Reasonable Criminal Risk ..................................................1644

5. Probable Administrative Risk ..............................................1645

6. Probable Criminal Risk .........................................................1646

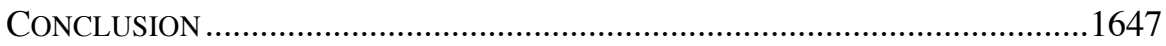




\section{INTRODUCTION}

This Article addresses an intriguing puzzle in corporate law: the differential treatment of business risk and legal risk. Business decisions, risky though they may be, fall under the duty of care. As long as they do not involve a conflict of interest, business decisions are judged under the deferential business judgment rule. ${ }^{1}$ Furthermore, companies can grant directors and officers exemptions from liability for negligent violations of the duty of care as well as insure them against personal liability in such cases. ${ }^{2}$ Decisions that violate the law, by contrast, constitute a violation of the duty of loyalty, ${ }^{3}$ and hence, they are not entitled to the deferential standard of the business judgment rule. As a consequence of this distinction, corporate managements can take on high-level business risks, but must steer clear of decisions and policies that involve minimal legal risks, even when the potential rewards are very high.

To illustrate, consider the following two examples. Assume that Jane Smith, the Chief Executive Officer ("CEO") of Acorn Inc., decides to construct a new production plant at a cost of $\$ 10,000,000$. In discussion with the board, she notes that based on the company's analysis of future business trends, there is an $80 \%$ probability that the construction of the new plant will generate a profit of $\$ 40,000,000$ for the company. However, there is a $20 \%$ chance of a global economic crisis, in which case the plant will not be built and the $\$ 10,000,000$ investment in the land will be lost. On these facts, the expected value of the transaction to the company is $\$ 32,000,000$, so Jane recommends that the company moves forward with the transaction. The board approves the plan. Unfortunately for the company, the risk of a global economic crisis materializes, and the company loses $\$ 10,000,000$.

Assume the same facts as before, with one difference: the company's parcel of land is in an area that is zoned for light industry and it is not clear whether Acorn's production plant is considered light or heavy. There is an $80 \%$ chance that the plant will be classified as light and a $20 \%$ chance that it will be classified as heavy. The expected gain and loss are exactly the same as in the previous example: the expected gain to Acorn is $\$ 32,000,000$ and the potential loss is $\$ 10,000,000$. The plant is built, but to the company's great chagrin, the municipality classifies it as heavy industry. The investment in the plant goes to waste, inflicting a $\$ 10,000,000$ loss on the company.

From an economic perspective, the two scenarios are identical in terms of the risks and the outcomes they produce. From a legal perspective, however, there

\footnotetext{
${ }^{1}$ See Aronson v. Lewis, 473 A.2d 805, 812 (Del. 1984) (explaining that business decisions categorically fall under duty of care imposed by business judgment rule), overruled by Brehm v. Eisner, 746 A.2d 244 (Del. 2000).

2 Joseph F. Johnston, Jr., Corporate Indemnification and Liability Insurance for Directors and Officers, 33 Bus. LAw. 1993, 1994-2005 (1978) (noting common practice of insuring business directors and officers from personal liability).

${ }^{3}$ For duty of good faith, see infra note 25 (illustrating how duty of good faith often supersedes alternative motivations).
} 
is a world of difference between them. The second scenario involves a legal risk. Violations of the law are considered breaches of the duty of loyalty and, as such, they cannot be insured against and are not subject to exclusions and exculpatory clauses. ${ }^{4}$ Consequently, the second decision exposes the management and board to personal liability if derivative actions are brought against them. The first decision, by contrast, would be analyzed as a potential violation of the duty of care under the deferential business judgment rule. ${ }^{5}$ Moreover, if a court finds the company's directors and officers negligent and orders them to pay damages to the company, the payments will be covered by their directors and officers liability insurance. ${ }^{6}$ Finally, it is possible that the directors and officers will not have to pay anything if their employment contracts contain exculpatory clauses. ${ }^{7}$

It should be emphasized that while our examples concern liability for active decisions, the distinction between business risks and legal risks is applicable to both commissions and omissions. In fact, the board's exposure to oversight liability is far greater when the oversight refers to a legal risk. ${ }^{8}$ As Chancellor Chandler stated in In re Citigroup Inc. Shareholder Derivative Litigation, ${ }^{9}$ "imposing Caremark-type duties on directors to monitor business risk is fundamentally different" than imposing those duties in the context of legal risk. ${ }^{10}$

The stark differentiation between business risk and legal risk under extant law gives rise to a puzzling question: What is the rationale behind this distinction? As persons trained in law, we may feel that the answer is straightforward: no one should break, or even consider breaking, the law. But this dogmatic approach does not comport with reality of risk. Firms face multiple business and legal uncertainties. Dealing with risk, business or legal, is an unavoidable aspect of the commercial world. Not all risks can be cost-effectively preempted or eliminated, irrespective of the source of the risk or the best efforts of the firm's directors and managers. Furthermore, from the vantage point of shareholders, all corporate decisions should be geared toward maximizing returns for shareholders. This does not mean, of course, that shareholders expect boards and managers to knowingly break the law. At the same time, there is no basis

${ }^{4}$ Del. Code AnN. tit. 8, § 102(b)(7) (2022) (stating that director liability may not be limited "[f]or any breach of the director's duty of loyalty to the corporation or its stockholders").

5 Aronson, 473 A.2d at 812 (illustrating deferential nature of business judgment rule).

${ }^{6}$ Johnston, supra note 2, at 2008.

7 Stephen M. Bainbridge, Caremark and Enterprise Risk Management, 34 J. CoRP.L. 967, 976 (2009) (“[M]ost corporate directors . . are insulated from monetary damage awards by exculpatory charter provisions.” (quoting Guttman v. Huang, 823 A.2d 492, 506 (Del. Ch. 2003))).

${ }^{8}$ In re Citigroup Inc. S'holder Derivative Litig., 964 A.2d 106, 131 (Del. Ch. 2009) ("There are significant differences between failing to oversee employee fraudulent or criminal conduct and failing to recognize the extent of a Company's business risk.").

${ }^{9}$ Citigroup, 964 A.2d 106.

${ }^{10} \mathrm{Id}$. at 131. 
for assuming that shareholders expect managers and boards to avoid legal risk, trivial though it may be, at all costs. Nor is it practical to harbor such an expectation, given the complex web of laws and regulations that engulfs the business world. Accordingly, the distinction between business risk and legal risk is far from trivial.

The challenge presented by the distinction between business risk and legal risk has not evaded legal scholars. Stephen Bainbridge has differentiated between the two forms of risk, claiming that while legal risk is dichotomous, in the sense that "you are either breaking the law or not," business risk "is inevitably intertwined with risk taking." 11 Unfortunately, Bainbridge's justification cannot carry the day. In some cases of legal risk, the uncertainty is not merely epistemic but also inherent in the operation of firms. Nor is Bainbridge's theory capable of explaining, even if it were correct, why firms should forego lucrative opportunities that stand to generate hefty profits only because the opportunities implicate a negligible level of legal risk.

In an important recent contribution, Professor Elizabeth Pollman suggested a different rationale for the distinction. According to Professor Pollman, the stricter approach to legal risk is intended to convey a clear and unequivocal message about the importance of respecting the law. ${ }^{12}$ While there is much to commend about Professor Pollman's expressive theory, it leaves the central puzzle intact. First, as is true of all expressive theories, it points us in a general policy direction but cannot prescribe the precise calibration of the message. Nor can expressive theories explain the exact contours of the doctrine. Second, it is unclear why the expressive message emanating from our criminal law regarding the duty to obey the law is insufficient and needs to be reechoed by our corporate law. ${ }^{13}$ Third, one must wonder whether the marginal expressive gain from adopting the distinction between legal and business risks outweighs the losses to firms and shareholders. In this context, it should be kept in mind that the shareholders in public corporations are the public at large.

In this Article, we seek to make two important contributions to corporate law scholarship. First, we advance a novel justification for the differential treatment of business risks and legal risks. Although from a general economic standpoint there is no difference between the two risks, there is a critical difference between them from the vantage point of the shareholders. Due to the board's exposure to personal liability for decisions involving legal risk, it will refuse to discuss opportunities that implicate legal risks, let alone carefully analyze them.

${ }^{11}$ Bainbridge, supra note 7, at 988.

12 Elizabeth Pollman, Corporate Oversight and Disobedience, 72 VAND. L. REV. 2013, 2029 (2019) [hereinafter Pollman, Corporate Oversight] ("Caremark itself can be viewed as a 'seminal "message" opinion,' catalyzing lawyers to advise corporate clients to put in place compliance systems and be mindful of oversight obligations.").

${ }^{13}$ Professor Pollman provides a historical explanation: in the past, corporations had much more detailed purpose clauses that considerably limited the scope of the corporation's activity. Those limitations have been relaxed overtime. Id. at 2019-20. 
Analysis of legal risk may constitute evidence of scienter - a culpable state of mind-and thus heighten the exposure of directors to legal sanctions. ${ }^{14}$ Realizing that boards will categorically oppose and veto any course of action that implicates a legal risk, management and employees, who stand to benefit from legal risk-taking, will elect not to bring such matters before the board. Hence, policies and decisions that run the risk of violating the law will eschew board discussion and oversight. No similar problem arises with respect to business risk. Consideration of business risk does not expose directors and officers to personal liability. On the contrary, it decreases the potential liability of directors for violating the duty of oversight. ${ }^{15}$

Our second intended contribution is more significant. Notwithstanding our novel justification for the distinction between business risk and legal risk, we argue that the line between the two should be redrawn. Not all legal risks are created equal. Following the traditional distinction in criminal law, we incorporate into our proposed framework the distinction between criminal prohibitions that fall into the category of mala in se and administrative proscriptions that fall into the category of mala prohibita. ${ }^{16}$ Prohibitions in the first category comport with our moral intuitions and are perceived as inherently wrong. Restrictions that belong in the second group do not address behavior that is considered morally wrong per se; rather, it is the legal ban that renders the activity impermissible.

To illustrate this distinction, compare theft and tax planning. Theft is considered a moral wrong independent of its legal prohibition. Reporting violations, by contrast, are not deemed immoral per se and often fall into the gray area in which right and wrong turn on intricate legal definitions. Furthermore, legal risk arises from legal uncertainty. There are varying degrees of uncertainty, however. Certain decisions are very risky from a legal

\footnotetext{
${ }^{14}$ Although on a formal level directors may be liable for illegal corporate conduct due to their failure of oversight even without knowledge of the illegal action, there are barely any cases in which such liability was imposed. See Elizabeth Pollman, Corporate Disobedience, 68 Duke L.J. 709, 756 (2019) [hereinafter Pollman, Corporate Disobedience] ("Despite widespread corporate illegality, there are few modern cases in which shareholders have successfully held directors liable for breaking the law."); Norwood P. Beveridge, Does the Corporate Director Have a Duty Always to Obey the Law?, 45 DePaul L. Rev. 729, 732 (1996) (" $[\mathrm{T}]$ here are no modern cases holding directors liable to shareholders for breaking the law."); Kent Greenfield, The Failure of Corporate Law: Fundamental Flaws \& Progressive PossibiLities 75 (2006) ("Indeed, there is not a single, modern case that holds directors liable to shareholders just because the directors or the corporation broke the law.").

15 Citigroup, 964 A.2d at 131 (explaining that oversight liability is far greater with legal risk than with business risk).

${ }^{16}$ For a discussion distinguishing between mala in se and mala prohibita with respect to legal risks, see Stephen M. Bainbridge, Star Lopez \& Benjamin Oklan, The Convergence of Good Faith and Oversight, 55 UCLA L. REV. 559, 592-93 (2008). As we will elaborate in Part IV, our distinction will operate differently than their suggestion, interacting with the level of risk and then leading to a distinctive liability regime.
} 
perspective. Others are only minimally risky. Corporate law is no stranger to this distinction. The Generally Accepted Accounting Principles ("GAAP") that have been endorsed by Securities and Exchange Commission ("SEC") regulations clearly distinguish between "remote" risks of loss that need not be included in financial reports, and reasonable and likely risks of loss that ought to be reported. ${ }^{17}$ Based on these distinctions, we propose to overhaul corporate law doctrine as it applies to legal risks. Instead of treating all legal violations as breaches of the duty of loyalty, we call for the adoption of a more nuanced approach that would differentiate between categories of legal violations based on their severity. In this vein, we suggest a distinction between potential violations of criminal prohibitions and possible violations of administrative norms. In the former case of risks that may lead to a criminal violation, directors and officers would only be allowed to consider remote legal risks, i.e., courses of action that are highly unlikely to violate the law. In the latter case of potential violations of administrative rules and regulations, directors and officers would be allowed to consider both remote and reasonable risks, i.e., courses of action that do not represent a probable likelihood of breaking the law. Importantly, our proposal submits that different levels of risk-taking be subject to differential liability regimes matching the level of the risk involved in the decision. Furthermore, our proposal would require corporate fiduciaries to provide external validation of their risk assessment.

The level of risk and the supporting evidence will determine the applicable judicial review standard. If a corporations's management and board are in possession of an administrative preruling that affirms the legality of the decision, the decision would be immune to judicial review. If the management and board relied on an expert opinion stating that there is only a remote risk of illegality, courts will review the substance of the opinion to ensure that it is wellgrounded. Finally, if the expert opinion on which the directors and officers relied states that their legal risk was reasonable-but not probable-the decision will be subject to enhanced scrutiny. Under this stricter standard, directors and officers would bear the burden of showing that the risk they chose to take was reasonable and that the expected benefits exceeded the potential harm. ${ }^{18}$

The adoption of our proposed framework would transform the way courts and corporations approach legal risk from outright disapproval to qualified sanctioning. And although implementation of our proposal would not place business risk and legal risk on equal footing, it would allow directors and officers to openly weigh and consider business strategies that involve an acceptable level of legal risk.

This Article unfolds in four parts. In Part I, we will discuss the differential treatment of business risk and legal risk under extant law. We will then show

\footnotetext{
17 See Fin. Acct. Standards Bd., Fin. Acct. Found., Proposed Accounting StANDARdS UPdATE: Contingencies (Topic 450) $1-5$ (2010), https://asc.fasb.org/imageRoot/73/6954873.pdf [https://perma.cc/DH83-MH34].

18 See Unocal Corp. v. Mesa Petroleum Co., 493 A.2d 946, 955 (Del. 1985).
} 
that the prevailing approach to legal risk may often result in destruction of value for shareholders. Against this backdrop, in Part II we explore existing justifications for the distinction between business risk and legal risk. We conclude that although the existing justifications have surface appeal, they do not survive scrutiny and therefore cannot provide a basis for said distinction. In Part III, we will advance a novel, process-oriented justification for the differential treatment of business risk and legal risk. First, we highlight how, under current law, directors will categorically refuse to consider decisions and policies involving legal risk. Then we argue that, as a result, their decisions will not be subject to the same exacting approval procedures as other policies and decisions. Consequently, the quality of policies and decisions implicating legal risks would be compromised. In Part IV, we will propose an alternative regime to govern legal risk. Under our proposal, board decisions involving legal risk would be subject to a differential standard of review depending on the probability of the risk (remote, reasonable, or probable) and the nature of the criminal norm implicated (mala in se or mala prohibita). A short conclusion will ensue.

\section{The Distinction BetweEn Business Risk AND LEGAL RisK}

The distinction between business risk and legal risk is part and parcel of corporate law. Decisions and policies involving business risk are adjudicated under the business judgment rule ("BJR"), which largely shelters managers and board members from personal liability for decisions that resulted in losses to their firms. ${ }^{19}$ Decisions and policies that implicate legal risk receive very different treatment. If a legal risk materializes, it exposes the directors and officers to liability for breach of the duty of loyalty. ${ }^{20}$ Breaches of the duty of loyalty do not fall within the ambit of the BJR. ${ }^{21}$ Nor are they typically subject to exculpatory clauses or directors and officers liability insurance. ${ }^{22}$ Worse yet, these breaches also expose directors and officers to criminal liability. ${ }^{23}$ Therefore, from the vantage point of directors and officers, managing business risks is part of their job description, while legal risks must be averted at all cost.

19 See, e.g., Aronson v. Lewis, 473 A.2d 805, 812 (Del. 1984), overruled by Brehm v. Eisner, 746 A.2d 244 (Del. 2000); Citigroup, 964 A.2d at 125 ("The presumption of the business judgment rule ... function[s] to place an extremely high burden on a plaintiff to state a claim for personal director liability for a failure to see the extent of a company's business risk."). Regarding the effective protection of BJR, see generally Lori McMillan, The Business Judgment Rule as an Immunity Doctrine, 4 WM. \& MARY Bus. L. Rev. 521 (2013).

${ }^{20}$ See, e.g., Abrams v. Allen, 74 N.E.2d 305, 306 (N.Y. 1947) (holding that directors may incur liability if they use corporate property for illegal purpose).

${ }^{21}$ See Miller v. AT\&T, 507 F.2d 759, 762 (3d. Cir. 1974).

22 See infra note 111 and accompanying text (demonstrating that duty of loyalty is not waivable for insurance purposes).

${ }^{23}$ See Miller, 507 F.2d at 763 (holding defendant directors can be found criminally liable if they breached their fiduciary duty to corporation). 
The distinction between business risk and legal risk does not originate in a specific statutory provision. Section 102(a)(3) of the Delaware Corporate Governance Law provides that the charter of corporations may include the particular goal for which they have been incorporated, or may simply state "that the purpose of the corporation is to engage in any lawful act or activity for which corporations may be organized[,] . . and by such statement all lawful acts and activities shall be within the purposes of the corporation." 24 Based on the statutory language that limits the corporate purpose to lawful aims and conduct, courts have determined that the duty of good faith requires directors and officers to be loyal to the corporation's legally authorized purposes, even if disobeying the law would maximize shareholder value. ${ }^{25}$ Chancellor Allen has defined the duty of loyalty as requiring directors to "manage the corporation within the law, with due care and in a way intended to maximize the long run interests of shareholders." 26 An important ramification of the duty to obey the law is the imposition of personal liability if fiduciaries knowingly violate the law. ${ }^{27}$ As

${ }^{24}$ Del. Code AnN. tit. 8, § 102(a)(3) (2022).

${ }^{25}$ In Cede \& Co. v. Technicolor, Inc., 634 A.2d 345, 361 (Del. 1993), the Delaware Supreme Court held that the duty of good faith is an independent and separate duty from the duty of loyalty. There is some dispute whether it actually matters if the duty of good faith is an independent duty or whether it is nested under the duty of loyalty. See Melvin A. Eisenberg, The Duty of Good Faith in Corporate Law, 31 DEL. J. CORP. L. 1, 15-16 (2006); Hillary A. Sale, Delaware's Good Faith, 89 CoRnell L. Rev. 456, 464 (2004) ("I argue that the courts have laid the groundwork for ... a freestanding duty [of good faith]."). The general consensus is that the question is mostly a semantic one. See Bainbridge et al., supra note 16, at 560 (noting that "good faith merely constitutes a 'subsidiary element' of director loyalty" (quoting Stone ex rel. AmSouth Bancorporation v. Ritter, 911 A.2d 362, 370 (Del. 2006))); Andrew S. Gold, The New Concept of Loyalty in Corporate Law, 43 U.C. DAVIS L. REV. 457, 459 (2009) (stating that "duty of good faith is a subsidiary component of the duty of loyalty"); Sean J. Griffith, Good Faith Business Judgment: A Theory of Rhetoric in Corporate Law Jurisprudence, 55 DuKE L.J. 1, 40-44 (2005) (explaining that duty of care and duty of loyalty are meant to answer same fundamental question); Leo E. Strine, Jr., Lawrence A. Hamermesh, R. Franklin Balotti \& Jeffrey M. Gorris, Loyalty's Core Demand: The Defining Role of Good Faith in Corporation Law, 98 GEO. L.J. 629, 640-44 (2010) (“[T]o divorce good faith from loyalty is to leave the fundamental and broad-reaching duty of loyalty without a definition . . .."); Robert B. Thompson, The Short, but Interesting Life of Good Faith as an Independent Liability Rule, 55 N.Y.L. ScH. L. REV. 543, 558-60 (2010) (noting that, under current law, duty of good faith has limited scope as independent theory of law).

26 TW Servs., Inc. v. SWT Acquisition Corp., Nos. 10427, 10298, 1989 WL 20290, at *7 (Del. Ch. Mar. 2, 1989).

27 See Metro Commc'n Corp. v. Advanced Mobilecomm Techs. Inc., 854 A.2d 121, 131, 163-64 (Del. Ch. 2004) (holding directors personally liable for violating duty of loyalty when they engaged in unlawful bribery for benefit of firm); Guttman v. Huang, 823 A.2d 492, 506 n.34 (Del. Ch. 2003) (“[O]ne cannot act loyally as a corporate director by causing the corporation to violate the positive laws it is obliged to obey."); In re Walt Disney Co. Derivative Litig., 907 A.2d 693, 755 (Del. Ch. 2005) (“A failure to act in good faith may be 
Vice Chancellor Strine stated in Desimone v. Barrows, ${ }^{28}$ "by consciously causing the corporation to violate the law, a director ... could be forced to answer for the harm he has caused." 29

The phrases "consciously causing" violations ${ }^{30}$ and "intent to violate" 31 are open to two possible interpretative approaches. The first approach is that the consciousness or knowledge required for such liability must pass some level of certainty. The second approach is that mere knowledge or awareness of the possibility that a certain action may cause a violation is sufficient for constituting such liability. Theoretically, it is possible to accept the first approach and exclude liability for duty of care violations from cases in which there is a certain level of uncertainty regarding the illegality of the action. The acceptance of such an approach would create partial symmetry, or at least prevent polar asymmetry, between the assumption of business risk and legal risk. Just as the exposure to business risk is permitted and fiduciaries are shielded from personal liability by the BJR, ${ }^{32}$ exposure to legal risk would be permitted in some instances and fiduciaries would be protected to a certain extent from personal liability. As we noted in the Introduction, one would expect a similar treatment of similar patterns of risk independent of their source. Even if a full symmetry between the two levels of risk is not adopted, one could expect at least a partial symmetry - that some level of legal protection is provided to fiduciaries' assumption of legal risk that benefits the corporation. Yet, in practice, courts in Delaware and elsewhere adopt the second approachcomplete asymmetry between business risk and legal risk - failing to provide protection to fiduciaries who expose the corporation to any level of legal risk. ${ }^{33}$ Fiduciaries are personally liable for any corporate legal risk that materializes. ${ }^{34}$

The asymmetry between business risk and legal risk is emphasized in Miller v. AT\&T. ${ }^{35}$ Miller, a shareholder in AT\&T, sued the company and its directors andofficers over the decision not to collect funds that they had transferred as

\footnotetext{
shown, for instance, $\ldots$ where the fiduciary acts with the intent to violate applicable positive law ....").

28924 A.2d 908 (Del. Ch. 2007).

29 Id. at $934-35$.

${ }^{30} \mathrm{Id}$. at 934.

31 Walt Disney Co., 907 A.2d at 755.

32 The BJR is designed "to increase stockholder wealth by engaging in those [business] risks that, in [directors'] business judgment, are in the best interest of the corporation 'without the debilitating fear that they will be held personally liable if the company experiences losses." 'In re Goldman Sachs Grp., Inc. S'holder Litig., No. 5215, 2011 WL 4826104, at *23 (Del. Ch. Oct. 12, 2011) (quoting In re Citigroup Inc. S'holder Derivative Litig., 964 A.2d 106, 139 (Del. Ch. 2009)).

${ }^{33}$ Miller v. AT\&T, 507 F.2d 759, 761-63 (3d. Cir. 1974) (holding that even wellcalculated legal risks are unfounded when legal duty is breached).

${ }^{34} \mathrm{Id}$.

35 Id. at 762.
} 
loans to the Democratic Party. ${ }^{36}$ Miller claimed that it was an illegal donation. .7 The court ruled that the BJR does not cover a calculated decision to expose the company to a legal risk. ${ }^{38}$ Accordingly, even though a decision not to collect a business loan is ordinarily covered by the BJR, a decision not to collect a loan that exposes the firm to a legal risk is excluded from its protective sphere. The distinction between business risk and legal risk has also seemingly been adopted by the American Law Institute. ${ }^{39}$

Nowhere is the differential approach to legal risk and business risk more accentuated than in the context of oversight liability. In In re Caremark International Inc. Derivative Litigation, ${ }^{40}$ the Delaware Court of Chancery recognized the possibility of imposing liability on directors for oversight failure if the board did not adopt an effective reporting system or ignored red flags. ${ }^{41}$ In Citigroup, Chancellor Chandler elucidated the challenge involved in oversight liability suits, explaining that "imposing Caremark-type duties on directors to monitor business risk is fundamentally different" than doing so when it comes to legal risk. ${ }^{42}$ This view has been reiterated in subsequent cases. ${ }^{43}$

${ }^{36} I d$. at 761 .

37 Id.

${ }^{38} I d$. at 762 (" $[\mathrm{W}] \mathrm{e}$ are convinced that the business judgment rule cannot insulate the defendant directors from liability if they did in fact breach [the relevant law] ....").

39 Principles of Corporate Governance: AnAlysis And ReCommendations $\S$ 4.01(a)-(b)(1) (АM. L. INST. 2008).

40698 A.2d 959 (Del. Ch. 1996).

${ }^{41} I d$. at 970 (“'[A] director's obligation includes a duty to attempt in good faith to assure that a corporate information and reporting system, which the board concludes is adequate, exists, and that failure to do so under some circumstances may, in theory at least, render a director liable for losses caused by non-compliance with applicable legal standards.").

${ }^{42}$ In re Citigroup Inc. S'holder Derivative Litig., 964 A.2d 106, 131 (Del. Ch. 2009). A similar understanding of Caremark has also been adopted in Corporate Risk Holdings LLC v. Rowlands, No. 17-cv-05225, 2018 WL 9517195, at *7 (S.D.N.Y. Sept. 28, 2018) (dismissing derivative suit against directors who did not monitor cybersecurity risks because it did not result from violation of law or employee misconduct).

43 See Asbestos Workers Loc. 42 Pension Fund ex rel. JPMorgan Chase \& Co. v. Bammann, No. 9772, 2015 WL 2455469, at *14 (Del. Ch. May 22, 2015) (explaining that alleged breach of duty of loyalty does not rise to level of business risk); In re Goldman Sachs Grp., Inc. S'holder Litig., No. 5215, 2011 WL 4826104, at*21-22 (Del. Ch. Oct. 12, 2011); Okla. Firefighters Pension \& Ret. Sys. v. Corbat, No. 12151, 2017 WL 6452240, at*18 (Del. Ch. Dec. 18, 2017); Reiter ex rel. Capital One Fin. Corp. v. Fairbank, No. 11693, 2016 WL 6081823, at*8 (Del. Ch. Oct. 18, 2016) (“"[T]his Court has been careful to distinguish between failing to fulfill one's oversight obligations with respect to fraudulent or criminal conduct as opposed to monitoring the business risk of the enterprise ...."). Regarding the cases that interpret Caremark as drawing the line between business risk and legal risk, see Pollman, Corporate Oversight, supra note 12, at 2043. 
Even though Delaware courts have not yet imposed liability on directors for violating their oversight duties, a few cases have survived motions to dismiss. ${ }^{44}$ All these cases dealt with claims concerning legal risks. ${ }^{45}$ In contrast, all motions

${ }^{44}$ Most recently, in Marchand v. Barnhill, 212 A.3d 805 (Del. 2019), the Delaware Supreme Court reversed the Chancery Court's dismissal of a breach of duty of loyalty claim against an ice cream company that had violated manufacturing regulations causing the death of three people. The other cases of suits against directors for oversight failure that survived a motion to dismiss all involved legal violations. See In re Clovis Oncology, Inc. Derivative Litig., No. 2017-0222, 2019 WL 4850188, at*6 (Del. Ch. Oct. 1, 2019) (involving failure to spot violation of Food and Drug Administration ("FDA") regulations for clinical trial protocols); In re China Agritech, Inc. S'holder Derivative Litig., No. 7163, 2013 WL 2181514 , at $* 18$ (Del. Ch. May 21, 2013) (reviewing failure to oversee use of proceeds of securities offering for stated purposes); In re Massey Energy Co., No. 5430, 2011 WL 2176479 , at $* 1$ (Del. Ch. May 31, 2011) (discussing claimed oversight of violation of mining safety laws and regulations); $c f$. La. Mun. Police Emps.' Ret. Sys. v. Pyott, 46 A.3d 313, 316 (Del. Ch. 2012) (involving failure to notice violation of FDA regulations of off-label marketing), rev'd, 74 A.3d 612 (Del. 2013); Am. Int'l Grp., Inc. v. Greenberg, 965 A.2d 763, 779 (Del. Ch. 2009) (involving failure to arrest and facilitation of sale of illegal financial products), aff'd sub nom. Tchrs.' Ret. Sys. of La. v. PwC, 11 A.3d 228 (Del. 2011). It should be noted that some of these cases, specifically American International Group and Pyott, are not classic Caremark suits for lack of oversight - there were some indications of the directors' active role in the violations. Am. Int'l Grp., 965 A.2d at 779; Pyott, 46 A.3d at 316. For an overview of the Caremark claims that passed a motion to dismiss and their common denominator of legal violations, see Pollman, Corporate Oversight, supra note 12, at 203641 .

45 Pollman, Corporate Oversight, supra note 12, at 2036 ("The small handful of Caremark cases that have survived this nearly insuperable standard on a motion to dismiss ... have all included facts that cross a line between business risk and legal risk."). City of Birmingham Retirement \& Relief System v. Good, 177 A.3d 47 (Del. 2017), reinforces the distinction between business risks and legal risks. A ruptured pipe owned by Duke Energy caused a spill of toxic wastewater into the Dan River. Id. at 50-51. The company paid a fine of $\$ 100$ million for the violations that contributed to the spill. Id. The justices of the Delaware Supreme Court were divided on whether to impose liability on the directors of Duke Energy for disregarding their oversight responsibility of such a violation. $I d$. at $64-65$. The majority of four justices ruled for dismissal of the claim against the directors; one justice-Chief Justice Strinedissented, arguing that the directors should be found liable. Id. Chief Justice Strine explained the difference between his opinion and the opinion of the majority as a disagreement about whether the directors deliberately exposed the company to legal risks. Id. at 65-69 (Strine, J., dissenting). Chief Justice Strine argued that even though the board had taken some measures to address regulatory concerns, it had "accepted and supported" a business strategy that "skirted" environmental laws and mitigated the legal risk by political influence-seeking. Id. at 65 . In contrast, the majority did not find that the board's behavior constituted deliberate exposure to legal risks, but rather that the plaintiffs were relying on a conflation between "the bad outcome of the criminal proceedings with the actions of the board." Id. at 59. Thus, according to Chief Justice Strine, all justices agreed that a board's knowledge of exposure to legal risk justifies imposing on directors personal liability. Id. at 65-69. The question in Birmingham was whether the board was aware that the firm was exposed to a legal risk. Id. 
to dismiss in cases involving business risks have been granted. ${ }^{46}$ In Salsitz v. Nasser ${ }^{47}$ the court explicitly noted that it would not impose liability on directors for losses to the firm arising from the materialization of a business risk. ${ }^{48}$ No such statement can be found with respect to legal risks. The clear distinction between business risk and legal risk with respect to oversight duty also underlies active decisions of fiduciaries, as we discussed above.$^{49}$ If courts distinguish between business risk and legal risk in the case of omissions of directors, providing lower protection for the latter, then a fortiori they afford even lower protection for the generation of legal risks through commissions.

As noted in the beginning of this Article, the distinction between business risk and legal risk is far from self-explanatory. From the point of view of the shareholders, the source or nature of the risk is irrelevant. The only variables that matter are the expected loss associated with the risk and the expected value of the policy or decision that gives rise to the risk.

\section{JUSTIFYING THE DiSTINCTION}

The problematic nature of the distinction between business risks and legal risks has not escaped the searching gaze of corporate law scholars. A review of the academic literature reveals several justifications that have been offered in support of the distinction. Some of these justifications address the distinction between business risk and legal risk head on. Other justifications do not address the distinction directly, yet we believe that they are relevant to the discussion. In the following paragraphs, we survey and critically evaluate all existing justifications for the differential treatment of business risk and legal risk.

\section{A. The Different Nature of Business Risk and Legal Risk}

Chancellor Chandler's opinion in Citigroup prompted Professor Stephen Bainbridge to advance a theory that supports the differential approach to business risks and legal risks. ${ }^{50}$ Although the decision dealt with oversight liability, Professor Bainbridge's justification of the distinction extends beyond the particular context of the case, covering both omissions and commissions. ${ }^{51}$ Professor Bainbridge's point of departure is that "[i]n fact, risk management and law compliance are not "fundamentally different." ${ }_{52}$ To support this proposition, he demonstrates that the professional literature does not treat the

\footnotetext{
46 Pollman, Corporate Disobedience, supra note 14, at 756.

47208 F.R.D. 589 (E.D. Mich. 2002).

${ }^{48} I d$. at 597 (holding that board's decision not to track safety record of Firestone tires, and manifestation of that associated risk, "is not a sufficient ground on which to hold the Defendants liable").

49 See supra note 32 and accompanying text (discussing BJR in context of fiduciaries).

${ }^{50}$ Bainbridge, supra note 7, at 968.

51 Id. at $979-81$.

${ }^{52}$ Id. at 979 (quoting In re Citigroup Inc. S'holder Derivative Litig., 964 A.2d 106, 131
} (Del. Ch. 2009)). 
two forms of risk differently. ${ }^{53}$ The Corporate Director's Guidebook, for example, addresses both risk and compliance in the same section. ${ }^{54}$ Furthermore, the actions that reduce business risk often have the effect of lowering exposure to legal risk, and thus put directors in good standing from a compliance perspective. Therefore, the ultimate goal of directors is to make sure that all the appropriate policies, methodologies, and infrastructure are in place. ${ }^{55}$

Yet, Professor Bainbridge believes that there is a difference in the nature of business risks and legal risks, which justifies the differential treatment of the two: "Whereas law compliance has something of an 'either/or' aspect-you are either breaking the law or not-business risk management is inevitably intertwined with risk taking." 56 The precise meaning of Professor Bainbridge's words is not entirely clear, and is thus open to interpretation. There are two possible ways to understand him. The first interpretation suggests that legal risk is binary, whereas business risk is not. The second is that legal risk can be fully averted, whereas business risk cannot; firms need not break the law but must make risky business decisions.

There are two problems with Professor Bainbridge's theory. First, neither interpretation of his justification holds water. As we will show, it is neither true that legal risks are binary, whereas business risks are not, nor is it true that legal risks can be avoided altogether. Second, his theory cannot provide a basis for the extant legal regime.

The claim that legal risk is binary in nature, whereas business risk is not, mischaracterizes the problem. All risks are binary in the sense that they either materialize or they do not. Of course, risks may partially materialize. But this is true for both business risks and legal risks. For example, a merger or an acquisition may partially fail and result in a loss that represents $50 \%$ of the maximum loss contemplated before the transaction. Similarly, an enforcement agency or a court may find that a company violated the law but might impose a fine that amounts to $50 \%$ of the maximum fine stipulated under the law. In the case of legal risks, the level of exposure and magnitude of the loss both depend on a host of factors, some of which are factual and some of which concern the blameworthiness of the perpetrators.

Professor Bainbridge's second argument - that legal risk can be fully averted whereas business risk cannot-fares no better. As Professor Norman

${ }^{53} I d$. at 990 ("Risk management does not differ in kind from the more typical law compliance and accounting control cases in which Caremark claims have been brought in the past.").

${ }^{54}$ Corp. L. Comm., ABA Bus. L. Section, Corporate Director's Guidebook-Seventh Edition, 75 Bus. LAw. 2741, 2775-82 (2020). For additional examples in the professional literature in which there is no distinction between the two forms of risk, see Bainbridge, supra note 7 , at 980 .

55 See Michel Crouhy, Dan Galai \& Robert Mark, The Essentials of Risk MANAGEMENT 30-33 (2006) (detailing strategic components of both business risks and legal risks).

56 Bainbridge, supra note 7, at 988. 
Beveridge - who served as the Chief Legal Officer of a Fortune 600 company (Amerace Corporation) ${ }^{57}$ before joining the academic world-has put it: "there is no such thing as a corporation ... in compliance with law; rather, there are only corporations (and businesses) out of compliance with the law to varying degrees." ${ }^{58}$ Professor Beveridge is correct. Companies operate in an intricate web of laws and regulations. In addition to corporate law and securities regulation, companies' activities interact with labor and employment discrimination laws, environmental and safety regulations, contract and tort law, and criminal law. Companies that operate overseas must be mindful of the foreign legal regimes of the sovereign countries where they conductbusiness. Compliance is a mammoth challenge that involves an endless process of information gathering and analysis. It is unrealistic to assume, therefore, that legal risk can be eliminated. A faithful portrayal of the real world reveals that neither business risks nor legal risks can be fully eradicated.

As a concrete example of our general point, consider the case of kickbacks to physicians. Pharmaceutical companies cannot offer kickbacks to doctors to induce the latter to recommend certain drugs or treatments. ${ }^{59} \mathrm{It}$ is possible for directors to oversee that the company does not have a systemized kickback policy. But this will not necessarily eliminate all local initiatives of individual employees to offer kickbacks to doctors in violation of the firm's policy. Even if a firm attempts to monitor all the interactions of its employees with doctors by mandating that all such interactions be recorded, it may not suffice. Agents, who are eager to improve their performance, may disregard the recording requirement or send a friend or a third party to provide the kickback. Of course, additional precautions may be put in place. For example, it is possible to require that every salesperson be accompanied by another to ensure compliance. Yet, even this measure can be circumvented, and the two employees can operate in cahoots to bypass the company's policy. It should also be remembered that, at some point, the marginal cost of each additional precaution will exceed the incremental benefit.

A similar dynamic can be seen in the case of bribery of government officials, a practice banned by the Foreign Corrupt Practices Act ("FCPA") ${ }^{60}$ Despite the ban and the attendant harsh consequences in the case of a violation, corporate agents may nonetheless have a strong individual incentive to bribe foreign government officers to increase their sales-based compensation. Here, too, a

57 See Alvin C. Harrell, A Tribute to Norwood Beveridge, 35 OKLA. City U. L. Rev. 247, 247 (2010).

58 Beveridge, supra note 14 , at 732.

5945 C.F.R. $§ 164.508$ (a)(3)(ii) (2020) ("If the marketing involves financial remuneration ... to the covered entity from a third party, the authorization must state that such remuneration is involved.").

${ }^{60}$ Foreign Corrupt Practices Act of 1977,15 U.S.C. $\S \S 78$ dd- 1 to -3 (prohibiting monetary influence over government and foreign officials). 
wide range of techniques may be employed to combat this risk, but none can eliminate it entirely.

A second problem with Professor Bainbridge's argument is that even if one were to agree with his premise that legal risk can be eliminated, it does not necessarily imply that it should be. Professor Bainbridge's explication makes the analytical error of conflating the "can" and the "should," but there is an analytical difference between the two. More importantly, from a policy perspective, clearly not everything that can be done should be legally prescribed. To illustrate our point, let us revisit the kickbacks problem. Assume that the only way to eliminate kickbacks from pharmaceutical companies to doctors requires the abolition of all conferences and academic events, as the interactions between pharmaceutical companies' employees and doctors provide ample opportunity for kickbacks. Should pharmaceutical companies be forced to not hold conferences? The answer is far from clear. Shareholders will bear a significant loss from this overly careful policy. Hence, it is reasonable to assume that they would want the company to refrain from going to such extremes and instead accept a certain exposure to legal risk. If a business strategy involves exposure to a remote legal risk associated with a small expected loss and a large potential gain, the shareholders may want the company to adopt it.

Our general point is simple: companies should be expected to approach all types of risk based on a comprehensive and careful analysis of the relevant losses and gains. Nor should companies be expected to avoid certain risks completely irrespective of the probability of the occurrence of those risks and the losses associated with them. Should a policy that is associated with a 0.002 probability of breaking the law and a small fine be dismissed out of hand even if it can yield a large expected gain to the shareholders? We believe that the answer should be no. Such a policy should be discussed and analyzed. We understand that a concern may arise that such an approach may result in violations of the law. Yet, this concern may, and should, be effectively addressed by increasing the sanctions associated with certain conduct and adjusting the level of enforcement.

\section{B. The Epistemic Justification for the Distinction}

An alternative way to understand Bainbridge's distinction between business risks and legal risks is as an epistemic distinction. The uncertainty that accompanies commercial risk is an objective uncertainty that is inherent in any business activity. In contrast, the uncertainty that is associated with legal risk is subjective uncertainty, in the sense that there is actually an answer to whether the practice is legal or not. ${ }^{61}$ And while it is possible that individuals and firms may not readily know the answer, they can reach it by seeking assistance from lawyers or judges. The same analysis does not apply to business risks because

${ }^{61}$ See Robert J. Rhee, The Effect of Risk on Legal Valuation, 78 U. CoLo. L. REV. 193, 200 (2007) (discussing legal assessment as a "subjective endeavor"). 
there is no objective way, let alone an institutional framework, to dispel business uncertainty. ${ }^{62}$

Similar to the previous justification, this justification faces a pair of obstacles. First, it is far from clear that the proposed epistemic distinction between the two types of risk is actually correct. Second, even assuming that the distinction is correct, it does not necessarily support the difference between the two typess of risks.

The proposition that every legal question has one right answer was suggested and popularized by the late legal philosopher Ronald Dworkin. ${ }^{63}$ Dworkin believed that legal dilemmas could always be resolved and that even the most challenging questions had a correct answer. ${ }^{64}$ It should be noted, though, that Dworkin adopted an ideal conceptualization of the law. Importantly, he never argued that actual courts always reach the right answer. ${ }^{65}$ Rather, he employed the construct of a "Herculean" judge and postulated that she would be able to reach the right answer. ${ }^{66}$ It should also be noted that Dworkin's theory, even with its provisos, has not been universally accepted ${ }^{67}$ Some scholars argue that

${ }^{62}$ For a similar distinction between legal uncertainty and enforcement uncertainty, see Yuval Feldman \& Doron Teichman, Are All Legal Probabilities Created Equal?, 84 N.Y.U. L. REV. 980, 981 (2009) (demonstrating that individuals treat differently legal risks and risks regarding enforcement uncertainty and are more risk averse in case of latter). An alternative way to explain the difference between the two forms of uncertainty is that in the case of legal uncertainty, the subject is endowed with the expected benefit of the interpretation that serves her interest. Regarding the concept of being endowed with the expected benefit in cases of uncertainty, see Adi Libson, Moral Uncertainty and Redistribution Through Private Law, 29 CANADIAN J.L. \& JuRIS. 371, 381-82 (2016).

63 See Ronald Dworkin, TAKING Rights SERIOUSLy 279-90 (1978) [hereinafter DWORKIN, TAKING RIGHTS SERIOUSLY] ("My arguments suppose that there is often a single right answer to complex questions of law ....").

${ }^{64}$ See Ronald Dworkin, No Right Answer?, in LAw, MORALITY, AND SOCIETY: ESSAYS IN HonOUR OF H.L.A. HART 58, 58-59 (P.M.S. Hacker \& J. Raz eds., 1977); DwORKIN, TAKING Rights SERIOUSLY, supra note 63, at 279-90; RonAld DwOrkin, A MATTER OF PrinCiPle 119-45 (1985) [hereinafter DwORKIN, A MATTER OF PRINCIPLE] (declaring that even hard questions of law have right answers); Ronald Dworkin, On Gaps in the Law, in Controversies About Law's Ontology 84, 84 (Paul Amselek \& Neil MacCormick eds., 1991).

65 Dworkin, TAking Rights Seriously, supra note 63, at 363 (conceding that not all judges arrive at right answer).

66 Ronald DwORKIn, LAW's EMPIRE 245, 263-65 (1986) [hereinafter DwORKIN, LAw's EMPIRE].

${ }^{67}$ See, e.g., Jeremy Waldron, Did Dworkin Ever Answer the Crits?, in EXPLORING LAw's EMPIRE: THE JuRISPRUDENCE OF RoNALD DWORKIN 155, 162-64 (Scott Hershovitz ed., 2006) (arguing that Dworkin has not refuted position of Critical Legal Studies that judges have strong discretion that enables them to choose between various possible judgments); see generally Joseph Raz, Dworkin: A New Link in the Chain, 74 CALIF. L. REv. 1103 (1986) (disagreeing with Dworkin's strict reading of law). 
Dworkin himself has retracted from his "one right answer" stance in his subsequent work, which developed the concept of legal interpretivism. ${ }^{68}$

Indeed, it is highly debatable that there is a correct answer to every legal question, even in the abstract. We are not aware of any jurist who argues that, in practice, all legal questions can be answered correctly. Justice Jackson essentially admitted it cannot be so when he said of himself and his fellow Justices, "[w]e are not final because we are infallible, but we are infallible only because we are final." 69 Similarly, according to the Holmesian conception, uncertainty is inherent in law. ${ }^{70}$ Justice Holmes defines law as " $[t]$ he prophecies of what the courts will do in fact, and nothing more pretentious." 71 Professor Frank Partnoy deduces from the Holmesian conception of law that the duty of directors and officers to comply with the law is to estimate what the regulators' position will be in the future..$^{72}$ According to this understanding of compliance with the law, there is no difference between business uncertainty and legal uncertainty. ${ }^{73}$ In both cases, one must foreshadow or estimate the outcome of future events.

But even if one accepts the epistemological distinction between business uncertainty and legal uncertainty, it does not follow that the disparate doctrinal treatment of the two risks is justified. From a practical standpoint, ascertaining the correct answer to intricate legal questions is too expensive for most individuals and many firms. ${ }^{74}$ It is unclear why the theoretical possibility of obtaining a correct answer generates the conclusion that one should obtain the answer irrespective of the cost involved. At the very least, the law, if based on this justification, should have reflected this factor by calibrating liability based

${ }^{68}$ Scott J. Shapiro, The "Hart-Dworkin" Debate: A Short Guide for the Perplexed, in RONALD DwORKIN 22, 35-36 (Arthur Ripstein ed., 2007) (book review) (noting Dworkin's changing perspective on legal positivism).

${ }^{69}$ Brown v. Allen, 344 U.S. 443, 540 (1953) (acknowledging that even Supreme Court sometimes hands down opinions that may merit reversal).

70 Oliver Wendell Holmes, Jr., Assoc. Just. of the Mass. Sup. Jud. Ct., The Path of the Law, Address at the Dedication of the New Hall of the Boston University School of Law (Jan. 8, 1897), in 10 HARV. L. ReV. 457, 466 (1897).

${ }^{71} \mathrm{Id}$. at 461 . The Dworkinian jurisprudence also supports this view. The fact that the court reached a certain decision regarding the legality of a given practice does not necessarily mean that their answer was the right answer all along, or that the court has merely discovered the preexisting law. According to the Dworkinian view, although there may be certain interpretations that are clearly wrong, there is a range of possible correct interpretations. Courts' decisions constitute the proper interpretations rather than merely discover them. See DWORKIN, LAW's EMPIRE, supra note 66, at 6.

72 Frank Partnoy, The Law of Two Prices: Regulatory Arbitrage, Revisited, 107 GEO. L.J. 1017,1040 (2019) (positing perspective that law is simply prediction of what regulators and judges will do in the future).

${ }^{73}$ Id.

${ }^{74}$ See DwOrKin, LAw's EMPIRE, supra note 66, at 6 (noting that there could be range of possible interpretations of given law). 
on the means of litigants and the cost of obtaining authoritative legal answers. Therefore, the epistemic distinction between business risks and legal risks does not provide a justification for their differential treatment under current doctrine.

\section{The Expressive Justification}

In a recent article, Professor Pollman offered another justification for the differential treatment of business risks and legal risks. ${ }^{75}$ According to Professor Pollman, the law's strict and uncompromising approach to legal risk is intended to convey an expressive message about the special importance of obeying the law. ${ }^{76}$ Professor Pollman acknowledges that there is no reason to assume that one source of risk is more pro-shareholder than the other-both business risks and legal risks can benefit shareholders to the same extent. ${ }^{77}$ Even though from the perspective of shareholders there is no difference between the two types of risk, the law differentiates between them in order to solidify the duty to adhere to and comply with legal standards.$^{78}$ The purpose of the distinction, therefore, is to strengthen the authority of the law and the rule of law, especially in the corporate context:

The fiduciary duty of good faith ... embeds a safety valve for public policy in the obligations of fiduciaries that cannot be eliminated. Expressing legal compliance and oversight obligations within corporate law acknowledges societal interests in the rule of law and preserves the ability of courts to flexibly respond to particularly salient and egregious violations of public trust, should they arise, without upending case law developed over decades. ${ }^{79}$

This view seems to suggest that allowing corporate fiduciaries to consider legal risks, even remote ones, would substantially harm the reverence of individuals toward the law. ${ }^{80}$ This is especially true in the corporate realm,

75 Pollman, Corporate Oversight, supra note 12, at 2043-44 (contending that difference between business risk and legal risk may be understood by looking at distinction "in light of corporate law's aim to further legal obedience and its own legitimacy").

${ }^{76} \mathrm{Id}$. at 2044 (discussing corporate law's uncompromising prohibition against engaging in legal risk).

${ }^{77}$ Id. at 2034 (considering potential social value or harm to shareholders created by engagement in either form of risk).

78 See Pollman, Corporate Disobedience, supra note 14, at 749 (noting that corporate law does not exempt actors from obligation to obey law). As Professor Pollman notes, the distinction leaves some wiggle room, enabling the exclusion of decisions that produce significant social value from the prohibition. $I d$. at 749-50. The problem with this kind of mechanism is that even when contemplating a decision to assume a legal risk with significant social value, the fiduciaries cannot be certain that their decision would be protected. Fiduciaries face considerable personal risk, and thus will still refrain from exposing the firm to legal risk even when it has considerable social value.

${ }^{79}$ Pollman, Corporate Oversight, supra note 12, at 2016-17.

${ }^{80} I d$. (stating that shareholders cannot be trusted to police corporate illegality). 
which is more susceptible to illegality than other spheres due to a wide range of behavioral effects that induce illegality, such as group decision-making, harm to unspecified individuals, and benefits conferred on third parties. ${ }^{81}$ According to this view, considerations of legal risk should not be allowed, regardless of the gains such risk may yield for shareholders. ${ }^{82}$

While there is much to commend about Professor Pollman's analysis, we find the expressive justification unsatisfactory. First, as many scholars have pointed out, ${ }^{83}$ it is not clear that expressive theories of the law have any independent weight. Expressive theories focus on the communicative function of the law, while remaining agnostic as to the substance of the underlying message. ${ }^{84}$ That is, expressive theories are not committed to a single value that ought to be promoted ${ }^{85}$ Rather, they accept the possibility of value pluralism. ${ }^{86}$ The desirability of expressive justifications ultimately depends on the substantive value the legal norm embodies. ${ }^{87}$ If the value underlying a legal norm is unjust or inefficient, there is no reason to amplify to it. ${ }^{88}$ In contrast, if the value a legal norm seeks to promote is just and noble, why not finetune and improve the substance of the norm itself? Professors Rick Pildes, Elizabeth Anderson, and Cass Sunstein have argued that expressive theories may be important, nonetheless, in cases where legal norms embody pluralistic values ${ }^{89}$ In these instances, expressive theories may be employed to mitigate conflicts between different values or to emphasize one message while deemphasizing another. ${ }^{90}$

${ }^{81}$ See Yuval Feldman, Adi Libson \& Gideon Parchomovsky, Corporate Law for Good People, 115 Nw. U. L. REv. 1125, 1165-66 (2021) (discussing corporate propensity for selfinterest as potential factor toward illegality).

${ }^{82}$ Pollman, Corporate Oversight, supra note 12, at 2013.

${ }^{83}$ See generally, e.g., Matthew D. Adler, Expressive Theories of Law: A Skeptical Overview, 148 U.PA. L. REV. 1363 (2000) (critiquing expressive theories of law).

${ }^{84}$ Elizabeth S. Anderson \& Richard H. Pildes, Expressive Theories of Law: A General Restatement, 148 U. PA. L. REv. 1503, 1565 (2000) (pointing out that expressive theories of law have nothing to say about "expressively 'meaningless"” acts).

${ }^{85}$ Richard H. Pildes \& Elizabeth S. Anderson, Slinging Arrows at Democracy: Social Choice Theory, Value Pluralism, and Democratic Politics, 90 Colum. L. Rev. 2121, 2154 (1990) (describing expressive theories as inherently open-ended).

${ }^{86} \mathrm{Id}$. at 2153 (noting, for example, that expressive concerns require interpretation to extend to new circumstances).

${ }^{87}$ Cass R. Sunstein, On the Expressive Function of Law, 144 U. PA. L. REV. 2021, 202728 (1996) (stating, for example, that society may insist on antidiscrimination law for expressive reasons even though they do not know whether law actually helps targeted group).

${ }^{88} \mathrm{Id}$. at 2034.

89 See Pildes \& Anderson, supra note 85, at 2145. For an elaborated account of the expressive view, see Anderson \& Pildes, supra note 84, at 1506-14, and Sunstein, supra note 87, at 2025-29.

90 Pildes \& Anderson, supra note 85, at 2147 ("When incommensurability is due to fundamental disagreements..., [expressive theories] merely conceal these deep disagreements"). 
Respect for the law, as Professor Pollman utilizes it, however, does not seem to fall in this category of cases. Additionally, even if one accepts the premise that respect for the law should be increased, it does not entail that the practice of taking legal risk should be banned altogether. Concretely, the expressive justification can explain why the law should take a stricter approach to legal risk-taking than to business risk-taking, but it cannot tell us what the precise calibration of the difference ought to be. Hence, one cannot infer from the expressive justification that considerations of legal risk should be taken off the table completely-only that business risk should be treated more leniently. Finally, there are alternative, more direct, ways to emphasize the importance of compliance with the law, such as increasing the sanction on legal violations by corporations. ${ }^{91}$ This course of action would increase deterrence and render potential violations unprofitable. ${ }^{92}$

\section{The Greater Risk Legal Risks Impose on Long-Term Shareholders}

Another theory that may justify the distinction between business risk and legal risk is that shareholders might be especially averse to legal risk-taking because it may expose them to abuses of discretion on the part of management. ${ }^{93}$ This theory assumes a correlation between fiduciaries' willingness to adopt an aggressive approach toward legal risk and their disregard for internal corporate norms and expectations. ${ }^{94}$ Under this theory, managers who are open to taking legal risks will also be prone to nominating close friends as directors, demanding excessive compensation, tunneling resources, or engaging in self-dealing. ${ }^{95} \mathrm{In}$ light of this dynamic, it is in the best long-term interest of shareholders that fiduciaries never contemplate breaking the law or consider exploiting legal gray areas. Hence, the prohibition on legal risk-taking ultimately benefits shareholders.

Studies by Professors Mihir A. Desai and Dhammika Dharmapala provide partial support for this theory. Professors Desai and Dharmapala have examined the impact of aggressive tax planning on share value. ${ }^{96}$ One would expect higher share prices in corporations that engage in aggressive tax planning for the simple

\footnotetext{
91 Garry S. Becker, Crime and Punishment: An Economic Approach, 76 J. Pol.Econ. 169, 199 (1969) (noting that stressing compensation would shift main purpose of legal proceedings to ensure that fines levied due to legal violations are equal to harm inflicted on society).

${ }^{92} I d$. (arguing that if optimal fines are levied as sanctions for legal violations, it would make engaging in such violations sufficiently unprofitable for firms).

93 Mihir A. Desai \& Dhammika Dharmapala, Corporate Tax Avoidance and Firm Value, 91 Rev. Econ. \& StAT. 537, 537 (2009) (suggesting, for example, that traditional view that corporate tax avoidance activity is necessarily beneficial to shareholders because it increases their value may not actually be so straightforward).

${ }^{94} \mathrm{Id}$. at 538.

95 Id. at 546.

${ }^{96} \mathrm{Id}$.
} 
reason that it increases the corporations' after-tax revenues. ${ }^{97}$ Surprisingly, Professors Desai and Dharmapala found the opposite correlation: as companies adopted more aggressive tax planning and paid less tax, their share prices were lower, everything else being equal. ${ }^{98}$ The most plausible explanation for this effect is that even though aggressive tax practices increase after-tax profits and thereby benefit shareholders, these practices signal to shareholders that management might utilize equally aggressive tactics to channel more funds into their own pockets at the expense of the shareholders. ${ }^{99}$ Professors Desai and Dharmapala's findings, at the very least, sound a cautionary note about the consequences of adopting a less than forthright approach to the law. Aggressive tax planning, after all, is but one example of a calculated approach toward legal restrictions. Hence, the same vicious circle identified by Professors Desai and Dharmapala may arise with respect to legal risk more generally.

Notwithstanding Professors Desai and Dharmapala's research, the hypothesis that assumption of legal risk exacerbates the managerial agency problem has not been endorsed by other scholars. ${ }^{100}$ We agree that, given the current state of knowledge, it is impossible to draw broad implications from the approach of directors and officers to legal risk and their ethicality vis-à-vis shareholders. First, as we emphasized earlier, legal risk cannot be avoided altogether. It is inherent in the activities and operations of corporations. ${ }^{101}$ Consequently, managements must adopt a strategy toward legal risk whether they like it or not. ${ }^{102}$ Second, it is impossible to extrapolate from Professors Desai and Dharmapala's work that shareholders perceive all legal risks in the same way, and more importantly, that they view all managerial responses to risk in an identical fashion. Professors Desai and Dharmapala's work focuses on aggressive tax planning and its signaling effects. ${ }^{103}$ It is highly doubtful that shareholders would perceive balanced and reasonable responses to legal challenges in a similar manner. In fact, there are reasons to believe that a responsible approach to legal risk may actually send a positive signal to shareholders. ${ }^{104}$

${ }^{97}$ Id. at 537.

${ }^{98} I d$. (noting that while tax avoidance should increase after-tax company revenues, effect is potentially offset by increased opportunities for rent diversion by tax shelters).

${ }^{99} \mathrm{Id}$. at 545-46.

100 See infra notes 102-03 and accompanying text.

101 See Beveridge, supra note 14, at 732.

102 See supra note 58 and accompanying text.

103 Desai \& Dharmapala, supra note 93, at 545 (noting that presumption that corporate tax avoidance automatically benefits shareholders by transferring value from state to shareholder pockets may not necessarily be validated by data collected in their studies).

${ }^{104}$ For instance, take the case of Airbnb, Tesla, Uber, and DraftKings discussed by Professors Pollman and Barry. Professors Pollman and Barry demonstrate how challenging existing regulation, leading even to regulatory transgression, is central to the business model and success of these "regulatory entrepreneurs." See Elizabeth Pollman \& Jordan M. Barry, Regulatory Entrepreneurship, 90 S. CAL. L. REv. 383, 384-85 (2017). The market does not 
Moreover, if the shareholders of a certain company worry that management's willingness to take on legal risk would develop into an "aggressive managerial culture," they can prohibit the assumption of legal risk in the company's charter or bylaws. ${ }^{105}$ For example, they could include a prohibition on establishing an offshore company for evading taxes. ${ }^{106}$ The central implication of Professors Desai and Dharmapala's analysis is that shareholders do not like aggressive managers. ${ }^{107}$ However, existing legal doctrine does not distinguish between aggressive and nonaggressive legal risk-taking; rather, it simply prohibits any legal risk-taking.

\section{A Novel JustificATION FOR THE DistinCTION: LACK OF EFFECTIVE OVERSIGHT ON LEGAL RISKS}

In this Part, we offer a novel justification for the distinction between business risk and legal risk. Unlike the justifications discussed in Part II, our justification is centered on corporate law and governance, rather than on external principles or general theories. As we will explain, we do not necessarily argue that our justification fully disposes of all the challenges that the distinction between business risk and legal risk poses, but it provides a stronger reason for treating these risks differently.

We argue that there is a critical difference between business risk and legal risk from the perspective of shareholders. The assumption of legal risk exposes not only directors and officers, but also shareholders, to personal losses. ${ }^{108}$ Under current doctrine, decisions that involve business risk are subject to

seem to deflate the value of these firms, despite their aggressive position to regulation. Id. at 401, $426 \mathrm{n} .226$ (noting that by time companies like Airbnb establish themselves on global scale, market will have shifted to favor their interests).

105 Geeyoung Min, Shareholder Voice in Corporate Charter Amendments, 43 J. CORP. L. 289, 289 (2018) (noting that shareholder approval for corporate charter amendments can serve as check against opportunism).

106 An example of a Corporate Charter Amendment in which shareholders deviate from practices prescribed by law is the adoption of a majority voting requirement in uncontested director elections. Most states impose a plurality standard for a director to be nominated, only requiring that she receive more votes than other contestants. Id. at 307. In quite a few companies, shareholders have pushed instead for a majority voting rule that requires a director to "receive more 'for' votes than 'withhold' votes". Id. (noting that between 2006 and 2013, shareholders amended charters to require majority voting standard over plurality voting standard in thirty-nine companies). Such a rule enhances the director's accountability to her shareholders because it requires her to reach a much higher level of active shareholder support to be nominated.

107 Desai \& Dharmapala, supra note 93, at 546 (suggesting that aggressive behavior like corporate tax avoidance and managerial efforts to divert funds from shareholders may be correlated).

108 See Pollman, Corporate Oversight, supra note 12, at 2043 (suggesting that harm to shareholders created by assumption of legal risk is arguable). 
effective oversight by the board while those implicating legal risk are not. ${ }^{109}$ As we emphasized throughout Parts I and II, the consideration of legal risk exposes board members to personal liability for breach of their fiduciary duty of loyalty if the risk materializes. ${ }^{110}$ Directors and officers liability insurance and exemptions do not apply to violations of the duty of loyalty. ${ }^{111}$ Nor can directors and officers seek the protection of the BJR in such cases. ${ }^{112}$ Breaches of the duty of loyalty also expose directors to criminal liability and social stigmatization. ${ }^{113}$ Thus, it is arguable that directors would prefer to avoid legal risk at all costs by steering clear of any decision or action involving legal risk and categorically refusing to discuss or analyze it. Board discussions of legal risk undermine directors' ability to benefit from one of the strongest criminal defense claims: that they were unaware of the illegality of the action. ${ }^{114}$ Furthermore, board members generally have limited advantage in taking on legal risk. ${ }^{115}$ Unlike

109 Id. at 2013.

$110 \mathrm{Id}$. at 2026.

111 See, e.g., DEL. CoDE ANN. tit. 8, § 102(b)(7) (2022) (barring Delaware corporations from eliminating directors' personal liability to corporation through certificates of incorporation "[f]or any breach of the director's duty of loyalty").

112 Bayer v. Beran, 49 N.Y.S.2d 2, 6 (Sup. Ct. 1944) (explaining that for directors, BJR "yields to the rule of undivided loyalty").

113 See, e.g., Securities Exchange Act of 1934, 15 U.S.C. $\$ 78 \mathrm{ff}$ (stating that breaches of duty of loyalty through insider trading violations are punishable by up to twenty years in prison).

${ }^{114}$ It is true that under the Caremark rule, boards are exposed to liability for legal violations - even if they had no awareness to the legal risk the firm was facing - if they utterly fail to "attempt in good faith to assure that a corporate information and reporting system ... exists." In re Caremark Int'l Inc. Derivative Litig., 698 A.2d 959, 970 (Del. Ch. 1996). Thus, the board digging its head in the sand in order to avoid awareness to legal risk will not protect it from liability. Yet, such responsibility is imposed only in extreme circumstances in which the firm, including the board, has purposefully structured a pattern in which the board is not notified even of the most basic and significant legal risk the firm is facing. See Pollman, Corporate Oversight, supra note 12, at 2028 (stating that obligation of obedience and oversight "allow corporate law to reflect public values and police extreme cases at the margins"). Marchand is an example of such extreme circumstances in which a Caremark claim regarding legal risk survived a motion to dismiss. Marchand v. Barnhill, 212 A.3d 805, 808 (Del. 2019) (holding that plaintiffs alleged sufficient facts to infer that Blue Bell's Board "failed to adopt or implement any reporting and compliance systems"). In Marchand, the management did not bring to the board's attention a letter from regulators noting that the firm may be transgressing laws and regulations regarding food safety, which are "intrinsically critical" to the firm's business - producing ice cream. $I d$. at 822 . This case exemplifies a situation in which the board did not merely fail to establish a reporting system for the firm's legal compliance, but also demonstrated complete disregard for the issue.

115 Quite a few dynamic, fast-growing, and even public companies that function as regulatory entrepreneurs are structured similarly to start-ups, in which the directors are founder entrepreneurs and venture capitalists. For the description of such firms and their structure, see Pollman \& Barry, supra note 104, at 398-99. 
managers' compensation, which is tightly pegged to performance, board members' compensation is contingent on the company's success, and is thus more limited. ${ }^{116}$ This stands in stark contrast to board members' personal loss in cases when the risk materializes. ${ }^{117}$ In addition, directors' absolute compensation derived from a specific firm is significantly lower than that of executives-directors tend to have a more diversified portfolio of income streams and are thus less dependent on the income they receive from a specific firm. ${ }^{118}$ The upshot is that when it comes to legal risk, directors are mainly exposed to the downside. ${ }^{119}$ Consequently, any issue of legal risk raised to the board will not be considered and board members will automatically vote against it. ${ }^{120}$ The directors' personal payoff balance is common knowledge and known to executives.

116 See Covington \& Burling LLP, Considering Director IndePEndence 1 (2007) (noting increased emphasis on director independence following enactment of Sarbanes-Oxley Act of 2002). This is especially true in relation to independent directors, who make up a majority of directors in U.S. public firms, given the requirement of U.S. stock exchanges that a majority of boards of publicly traded companies be independent. Id. Inside directors are more sensitive because they may be holding a large stake of the firm's shares. A study comparing CEO compensation and director compensation that examined panel data of over 1,000 firms between 1992 and 2001 found that the cash element in CEO compensation is almost double that in director compensation: over $40 \%$ for the former and $26 \%$ for the latter. See Ivan E. Brick, Oded Palmon \& John K. Wald, CEO Compensation, Director Compensation, and Firm Performance: Evidence of Cronyism?, 12 J. CORP. FIN. 403, 408 (2006). But the gap in the sensitivity of their compensation to performance is much larger. In general, independent directors' compensation, unlike executive compensation, rarely includes an option component. See id. at 410 (concluding that director total compensation is "positively related to the need for monitoring and the difficulty of the directors' tasks"). Even when it includes a stock component, in many cases it is a fixed-value stock component, which is insensitive to the performance of the stock. This is more prevalent than the fixed-number stock component which is sensitive to performance. The prevalence of the fixed-value component at the expense of the fixed-number component is only growing in the last years. See, e.g., Kathleen A. Farrell, Geoffrey C. Friesen \& Philip L. Hersch, How Do Firms Adjust Director Compensation?, 14 J. CORP. FIN. 153, 157 (2008). The literature on director compensation is relatively modest in comparison to that of CEO compensation, and thus does not provide a detailed picture of directors' compensation packages. $C f$. SANJAI BHAGAT, FinANCIAl CRisis, Corporate Governance, AND BANK CAPITAL 101, 101 (2017).

117 See Pollman, Corporate Oversight, supra note 12, at 2022 (noting, for example, that in Caremark, shareholders brought derivative suits against board to hold members individually liable for negative outcome of risk).

118 See Brick et al., supra note 116, at 408 (considering study of panel data of over 1,000 firms between 1992 and 2001, which found that average total compensation of CEOs was $\$ 4,054,703$ in comparison to $\$ 67,225$ for directors).

119 See Beveridge, supra note 14, at 730 (stating that board of directors must bear personal liability to employer for failing to adhere to legal requirements).

${ }^{120} I d$. at 732 n. 17 . 
The perspective of executives on legal risk is quite different from those of directors. Executives too may incur personal liability if a legal risk materializes. ${ }^{121}$ However, because their compensation is tied to the performance of the firm, executives may have an incentive to assume legal risk if the potential rewards are high enough. Aware of the board's negative disposition toward legal risk, executives may consciously elect not to raise opportunities involving legal risk with the board to keep the opportunities alive. ${ }^{122}$ This strategy of suppression yields another benefit to the executives by allowing them to claim that they were unaware of the illegality of their actions. ${ }^{123}$

The fact that the board closely scrutinizes decisions involving business risk, but not decisions implicating legal risk, does not justify the differential treatment of these risks. Board oversight is one of the chief protective mechanisms afforded to shareholders. ${ }^{124}$ However, dispersed shareholders cannot be relied on to effectively monitor management. ${ }^{125} \mathrm{~A}$ vast literature suggests that dispersed shareholders have neither the ability nor the incentive to perform this task. ${ }^{126}$ Monitoring requires substantial financial and cognitive resources. ${ }^{127} \mathrm{An}$ individual shareholder who wishes to take on this task stands to incur significant expenditures while reaping a tiny portion of the benefits - only her percentage

${ }^{121}$ Donald C. Langevoort, On Leaving Corporate Executives "Naked, Homeless and without Wheels": Corporate Fraud, Equitable Remedies, and the Debate over Entity Versus Individual Liability, 42 WAKE FOREST L. REV. 627, 628 n.6 (2007) (offering examples of personal liability to executives as result of materialization of legal risk, such as high probability of job loss and drop in stock value of securities holdings).

${ }^{122} I d$. at 644 (arguing that executives, as opposed to board members, are better positioned to assume such risk).

${ }^{123}$ Even though executives may be held liable for oversight failures, there are barely any cases in which such liability has been imposed. See Beveridge, supra note 14, at 732 (1996); Pollman, Corporate Disobedience, supra note 14, at 756 (noting limited success of shareholders in holding directors liable for breaking law despite prevalence of corporate illegality); GREENFIELD, supra note 14, at 75 (2007).

124 See Beveridge, supra note 14, at 730 (describing shareholders' right to hold board liable for breaking law).

125 John C. Coffee, Jr., Shareholders Versus Managers: The Strain in the Corporate Web, 85 Mich. L. REV. 1, 15 (1986) (reflecting on essential powerlessness of dispersed shareholders in ousting managers from office).

126 See id. ("Berle and Means reported that the separation of ownership and control in the modern corporation had left shareholders effectively powerless, as managers could neither be ousted from office by shareholders who were widely dispersed, and therefore incapable of coordinated action, nor disciplined effectively by the capital market ...."); see also John C. Coffee, Jr., The Rise of Dispersed Ownership: The Roles of Law and the State in the Separation of Ownership and Control, 111 YALE L.J. 1, 5 (2001) (suggesting that only controlling shareholders enjoy private benefits of control); Ronald J. Gilson, Controlling Shareholders and Corporate Governance: Complicating the Comparative Taxonomy, 119 Harv. L. Rev. 1641, 1652 (2006); Adolf A. Berle, Jr. \& Gardiner C. Means, The Modern CORPoration AND Private Property 132 (1933).

127 Gilson, supra note 126 , at 1652. 
of the company's share. The lion's share of the benefit will be distributed among all other shareholders. It is similarly unrealistic to expect masses of anonymous shareholders to collectively monitor the board. ${ }^{128}$ For this reason, the board has the immutable duty of overseeing management. ${ }^{129}$

By assuming the role of overseer, the board overcomes the collective action problem that plagues dispersed shareholders. ${ }^{130}$ As the importance of the policy or decision facing a company increases, so does the significance of board oversight. In the case of decisions that involve business risk, shareholders can rest assured that such decisions pass two levels of review-the management level and the board level. ${ }^{131}$ Decisions and policies that implicate legal risk will not be subject to the same dual scrutiny. ${ }^{132}$

Naturally, our justification is not above criticism. One possible critique of our theory is that it overstates the importance of board oversight for shareholders. Several eminent scholars have noted that, in practice, boards do not effectively monitor the management of firms. ${ }^{133}$ Although the shareholders formally nominate directors, in practice, the management mostly controls the nomination process by deciding which candidates are up for election. ${ }^{134}$ Consequently, directors will try to appease management, either to express their gratitude or to increase the probability of being reelected. ${ }^{135}$

${ }^{128}$ Reinier H. Kraakman, Corporate Liability Strategies and the Costs of Legal Controls, 93 YALE L.J. 857, 889 (1984) (commenting on risk of absolute liability when gatekeepers have active duty to monitor); Paul L. Lee, Risk Management and the Role of the Board of Directors: Regulatory Expectations and Shareholder Actions, 125 BANKING L.J. 679, 711 (2008).

129 See infra notes 151-53 and accompanying text (discussing board's immutable duty to monitor as prescribed by corporate law); see also Bernard S. Black, Shareholder Passivity Reexamined, 89 Mich. L. ReV. 520, 533 (1990).

${ }^{130}$ Iman Anabtawi \& Lynn Stout, Fiduciary Duties for Activist Shareholders, 60 STAN. L. REV. 1255, 1262 (2008) (noting that directors and officers owe corporation and shareholders duty of care "by acting on an informed basis, in good faith, and in the honest belief that their actions are in the best interests of the corporation").

131 See Kraakman, supra note 128, at 861 (noting managers and directors' high degree of personal liability for business decisions).

132 See Pollman, Corporate Oversight, supra note 12, at 2044.

133 See, e.g., Steven Boivie, Michael K. Bednar, Ruth V. Aguilera \& Joel L. Andrus, Are Boards Designed to Fail? The Implausibility of Effective Board Monitoring, 10 ACAD. MGMT. ANNALS 319, 320 (2016) (questioning practical relevance of boards other than serving "as groups packed with close friends of the CEO that simply acted as rubber stamps for management proposals").

${ }^{134}$ William K. Sjostrom, Jr. \& Young Sang Kim, Majority Voting for the Election of Directors, 40 ConN. L. Rev. 459, 466 (2007) ("Management controls all aspects of the proxy materials and, of course, uses this control to ensure [its nominees] are elected. . . Thus, it is generally not possible for a shareholder to use the corporation's proxy card to instruct the proxy to vote for someone other than a nominee listed on the card.").

135 Yaron Nili, The "New Insiders": Rethinking Independent Directors' Tenure, 68 Hastings L.J. 97, 122 (2016); see Barry Baysinger \& Robert E. Hoskisson, The Composition 
We believe this argument goes too far. While a debate exists in the academic literature regarding the efficacy of the board in monitoring management or shareholders, no one argues, to the best of our knowledge, that board monitoring is completely ineffective. ${ }^{136}$ Even if it is true that the board is more attuned to the preferences of management than to those of shareholders, this does not mean that the board flouts its monitoring responsibility or is completely insensitive to the interests of shareholders. All the criticism suggests is that the level of monitoring is not optimal. ${ }^{137}$

Only a relatively small percentage of the decisions made by management implicate the narrow self-interests of its members. ${ }^{138}$ Most of the decisions that are brought to the board do not involve conflicts between management and shareholders' interests. Hence, in the ordinary course of events, board monitoring constitutes an important mechanism of protecting the interests of shareholders.

Furthermore, even in cases where managerial interests conflict with those of the shareholders, the board should not be thought of as a mere rubber stamp in

of Boards of Directors and Strategic Control: Effects on Corporate Strategy, 15 ACAD. Mgmt. Rev. 72, 72-73 (1990) (noting that "managers dominate their boards by using their de facto power to select and compensate directors and by exploiting personal ties with them").

136 See Stephen M. BAinbridge, Corporation LAw And Economics 37 (2002) ("The apparent lack of managerial accountability inherent in modern corporate structure has troubled legal commentators ....").

137 See id. (acknowledging and contextualizing lack of managerial accountability in modern corporations); Lucian A. Bebchuk, The Myth of the Shareholder Franchise, 93 VA. L. Rev. 675, 685 (2007); William K. Sjostrom, Jr., The Case Against Mandatory Annual Director Elections and Shareholders' Meetings, 74 TENN. L. REv. 199, 216 (2007) (noting that while election of directors in most cases is nothing more than charade, there have been recent proposals to make elections more meaningful).

138 According to some scholars, the main function of the board is not merely to supervise management, but to serve as an additional tier for analyzing managerial strategic decisions. This model of boards is dubbed the managerial model of boards. See Renée B. Adams \& Daniel Ferreira, A Theory of Friendly Boards, 62 J. Fin. 217, 218 (2007) (discussing board's monitoring role as active participation in firm's decision making); Milton Harris \& Artur Raviv, A Theory of Board Control and Size, 21 Rev. Fin. Stud. 1797, 1798 (2008) (considering how board control affects board decisions and shareholder value); Fenghua Song \& Anjan V. Thakor, Information Control, Career Concerns, and Corporate Governance, 61 J. FIN. 1845, 1847 (2006). According to these board models, the board's central function is not limited to instances in which management may be conflicted. However, some scholars view the supervision of the managerial decision-making process as the main function of the board. This approach is dubbed the supervisory role of boards. See Benjamin E. Hermalin \& Michael S. Weisbach, Endogenously Chosen Boards of Directors and Their Monitoring of the CEO, 88 AM. ECON. REv. 96, 99 (1998); Andres Almazan \& Javier Suarez, Entrenchment and Severance Pay in Optimal Governance Structures, 58 J. FIN. 519, 521 (2003). It should be noted that this dispute is both normative and descriptive-considering what function boards fulfill and analyzing the impact of various features of the board on managerial decision-making. 
the hands of the managers. First, not all directors are effectively nominated by the management. ${ }^{139}$ Quite a few directors nominated against the will of management, after receiving support from hedge funds or institutional investors. ${ }^{140}$ Second, not everyone views directors as calculating self-interestmaximizers. Directors may be driven by other motivations, such as maintaining their self-image as ethical actors. ${ }^{141}$ Third, market forces exert a disciplining effect on directors by mitigating their tendency to side with management. Because firm performance affects the reputation of directors and their future earnings, directors cannot afford to blatantly disregard the interests of shareholders. ${ }^{142}$ Finally, what market forces leave unaddressed is picked up by the law, which imposes a duty of care and a duty of loyalty on directors to ensure that they act in the best interests of shareholders. ${ }^{143}$ The purpose of these duties is to create as perfect an alignment as possible between the interests of directors and shareholders. ${ }^{144} \mathrm{We}$ do not claim, of course, that the law accomplishes this result. We simply argue that the law has some effect on the behavior of directors. ${ }^{145}$ The idea that legal proscriptions and associated sanctions affect subjects' behavior is the foundation of all legal systems. ${ }^{146}$ Unsurprisingly, this effect is also present in the corporate world. ${ }^{147}$ A review of the literature reveals

139 Almazan \& Suarez, supra note 138, at 521.

140 See Assaf Hamdani \& Sharon Hannes, The Future of Shareholder Activism, 99 B.U.L. REv. 971, 993-94 (2019) (discussing how, in many of these contests, activists are backed by institutional investors). In 2020, 131 directors suggested by activists won seats on corporate boards: 24 in proxy fights and 107 through settlement. In 2018 the number was even higheractivists won 157 seats against the will of management. See LAZARD, 2020 REviEw OF SHAREHOLDER ACTIVISM 14 (2021).

${ }^{141}$ Feldman et al., supra note 81 , at 1144.

142 Armen A. Alchian \& Harold Demsetz, Production, Information Costs, and Economic Organization, 62 AM. ECON. REv. 777, 788 (1972) (“[P]olicing of managerial shirking [in the corporate context] relies on across-market competition from new groups of would-be managers as well as competition from members within the firm who seek to displace existing management.").

143 See Randy J. Holland, Delaware Directors' Fiduciary Duties: The Focus on Loyalty, 11 U.PA. J. Bus. L. 675, 683, 700 (2009) (noting directors' personal liability to shareholders upon breach of duty of care and "quasi-trustee and agency relationship" to shareholders under duty of loyalty (quoting Schoon v. Smith, 953 A.2d 196, 206 (Del. 2008))).

${ }^{144} I d$.

${ }^{145}$ Lisa M. Fairfax, Spare the Rod, Spoil the Director? Revitalizing Directors' Fiduciary Duty Through Legal Liability, 42 Hous. L. REv. 393, 432 (2005) (arguing that inability of market and reputational forces to ensure directors behave properly suggests need for legal sanctions).

146 See id. at 439.

${ }^{147} I d$. (considering study that found legal sanctions had deterrent effect on decision to engage in illegal corporate acts). 
that directors are sensitive and responsive to the duties corporate law imposes on them..$^{148}$

Another possible criticism that may be raised against our proposed justification of the difference between business risk and legal risk is an objection we addressed in our discussion of preexisting justifications. Namely, instead of adopting a prophylactic ban on legal risk-taking, lawmakers should allow firms and shareholders to contractually set the level of legal risk-taking that is right for them. Doing so would permit risk-averse shareholders to ban directors and officers from taking on any legal risk, while allowing shareholders who are less averse to legal risk to empower corporate fiduciaries to assume certain legal risks. In short, private ordering would enable shareholders to decide for themselves whether such risks serve or harm their interests.

While reliance on private ordering clearly has surface appeal, its shortcomings become apparent upon closer examination. In a world without transaction costs and perfect information, shareholders could rely on private ordering to protect their interests and tailor the level of protection for their risk preferences. ${ }^{149}$ In the real world, positive transaction costs and asymmetric information prevent shareholders from protecting their interests against managerial abuse. ${ }^{150}$ For this reason, corporate law does not exclusively rely on default arrangements that can be modified contractually; rather, it complements them with mandatory protections for shareholders that cannot be contractually waived. ${ }^{151}$ One example of such mandatory protections is the duty of a company

148 See Robert Flannigan, The Economics of Fiduciary Accountability, 32 DEL. J. CORP. L. 393, 427-28 (2007) (concluding that fiduciary duties are effective in preventing self-dealing, even though market forces can also play role in deterring fiduciaries from self-dealing transactions); see also Simon Deakin \& Alan Hughes, Directors' Duties: EMPIRICAL FINDINGS 31 (1999).

149 The most famous example of shareholders rejecting a clause intended for their protection is Smith v. Van Gorkom, 488 A.2d 858 (Del. 1985), in which the shareholders of many firms exculpated fiduciaries from the duty of care meant to protect shareholders. The prevailing explanation for this change is that Van Gorkom increased the liability of fiduciaries, which in turn increased the price for shareholders by the higher price firms had to pay to insure executives. Shareholders determined that the protection that the duty of care offers them was not worth the price they paid. See Yaron Brook \& Ramesh K.S. Rao, Shareholder Wealth Effects of Directors' Liability Limitation Provisions, 29 J. FIN. \& Quantitative Analysis 481, 483 (1994) (describing the "directors' liability crisis" that followed Van Gorkom).

150 See, e.g., Bernard S. Black, Is Corporate Law Trivial?: A Political and Economic Analysis, 84 Nw. U. L. REV. 542, 551-53 (1990) (discussing correlation between transaction costs and uniformity of corporate preferences).

151 See id. (citing self-dealing rules as one example of mandatory law); Melvin Aron Eisenberg, The Structure of Corporation Law, 89 CoLUM. L. REV. 1461, 1486 (1989) (arguing self-dealing rules are "largely mandatory, at least for publicly held corporations"); Marcel Kahan, The Qualified Case Against Mandatory Terms in Bonds, 89 Nw. U. L. REv. 565, 607 n.164 (1995) (claiming rules on self-dealing by managers are mandatory); Randall S. Thomas, What Is Corporate Law's Place in Promoting Societal Welfare?: An Essay in Honor of 
to its board: shareholders in public companies cannot relinquish their right to nominate a board.152 Nor can the board abdicate its duty to monitor management, even if the majority of shareholders consent to this eventuality. ${ }^{153}$ Corporate law perceives the board as an indispensable organ that is essential for the protection of shareholders against managerial abuse. ${ }^{154}$ Similarly, the duty of loyalty of corporate fiduciaries is an immutable duty that cannot be waived or modified contractually. ${ }^{155}$ These mandatory obligations provide shareholders

Professor William Klein, 2 BERKELEY BUS. L.J. 135, 139 (2005) (stating self-dealing rules are mandatory for public corporations).

152 See, e.g., DEL. CodE ANN. tit. 8, § 242(b)(1) (2022) (describing requirements for proper amendments to certificate of incorporation); MODEL Bus. CORP. ACT $\S 10.03$ (a)-(b)(1) (AM. BAR ASS'N 2016) (requiring changes in corporate charter to be approved by board); see also Edward P. Welch \& Robert S. Saunders, Freedom and Its Limits in the Delaware General Corporation Law, 33 DEL. J. CoRP. L. 845, 846, 857-58 (2008). In 1989, the Columbia Law Review published a Symposium on mandatory provisions in corporate law. The following scholars have supported and justified mandatory corporate provisions: John C. Coffee, Jr., The Mandatory/Enabling Balance in Corporate Law: An Essay on the Judicial Role, 89 Colum. L. Rev. 1618, 1690-91 (1989) (noting benefits of mandatory rules that force certain parties to bargain and contract more effectively); Eisenberg, supra note 151, at 1524-25 (emphasizing particular importance of mandatory rules in context of publicly held corporations versus closely held corporations); Jeffrey N. Gordon, The Mandatory Structure of Corporate Law, 89 Colum. L. Rev. 1549, 1597-98 (1989) (describing two main decisionmakers that determine application of mandatory rules as courts and legislature). The Symposium also included contractarian scholars that represented the more critical view toward mandatory provisions. See Frank H. Easterbrook \& Daniel R. Fischel, The Corporate Contract, 89 CoLuM. L. Rev. 1416, 1446-48 (1989) (dismissing questions about corporation's goal when choosing to adopt approach that centers on corporation's contractual nature); Fred S. McChesney, Economics, Law, and Science in the Corporate Field: A Critique of Eisenberg, 89 CoLuM. L. REv. 1530, 1544 (1989) (criticizing Eisenberg's approach as not proving that government-imposed mandatory rules would benefit shareholders); Roberta Romano, Answering the Wrong Question: The Tenuous Case for Mandatory Corporate Laws, 89 Colum. L. REV. 1599, 1615-16 (1989) (arguing against mandatory rules because hypotheses in support do not provide appropriate criteria for predicting substance of mandatory rule ahead of time).

153 See Del. CodE AnN. tit. 8, § 141(a) (2022) ("The business and affairs of every corporation organized under this chapter shall be managed by or under the direction of a board of directors, except as may be otherwise provided in this chapter or in its certificate of incorporation.”); see also Order Granting Plaintiffs' Motion for Judgment on the Pleadings at 8, Schroeder v. Buhannic, No. 2017-0746 (Del. Ch. Jan. 10, 2018) (holding that shareholders' agreement cannot deprive board of its statutory authority to manage corporate affairs and appoint officers).

${ }^{154}$ Lucian Arye Bebchuk \& Assaf Hamdani, Optimal Defaults for Corporate Law Evolution, 96 Nw.U.L. REv. 489, 496 n.16 (2002).

155 See Welch \& Saunders, supra note 152, at 846,859-60; see also Bebchuk \& Hamdani, supra note 154 , at $496 \mathrm{n} .16$ (providing duty of loyalty of corporate directors as example of mandatory corporate governance regulation). It should be noted that since 2000, Delaware enables a waiver of a partial element of the duty of loyalty - the restriction on corporate 
with a legal safety net, the purpose of which is to reduce monitoring costs for the shareholders. ${ }^{156}$ Finally, one could raise the question: Why not extend the BJR to legal risk? Applying the BJR to decisions involving legal risk, so the argument goes, would put business risk and legal risk on a par from the vantage point of directors, allowing them to review decisions involving legal risk. ${ }^{157}$ If the BJR applied to legal risk, directors would not shy away from decisions involving legal risk and executives would bring such decisions to the board. ${ }^{158}$ This argument is in error. While extending the BJR to legal risks would shelter directors against derivative actions, it would not immunize them against criminal liability. ${ }^{159}$ The BJR has no effect on criminal law and criminal sanctions have a much stronger deterrent effect than civil remedies. ${ }^{160}$ In order to equalize both risks, it would be necessary not only to change the scope of the $\mathrm{BJR}$, but also to reform criminal law and relieve directors from criminal liability for decisions they make.

We strongly caution against making this change. There are weighty policy and practical reasons not to adopt it. From a policy standpoint, relieving directors of criminal liability for harms arising from the materialization of legal risk would legitimize massive legal violations behind the corporate veil. This, in turn, would create an opportunity for an undesirable legal arbitrage: it would likely lead individual offenders to set up corporations to take advantage of the legal protection they provide. Sophisticated offenders would be more likely to use this option, whereas small time offenders would not. Practically, exempting directors from criminal liability requires a large-scale reform that involves many settled doctrines. The costs associated with such a reform are likely to be very high - not to say, prohibitive-and, in our opinion at least, they will far outweigh the benefits.

Accordingly, we believe that the distinction between business risk and legal risk should not be eradicated. The approach to legal risk should be stricter than that of business risk. This approach, however, does not imply that consideration of legal risk should be banned altogether. Rather, our discussion points us in a different direction. Instead of maintaining a sharp dichotomy between business

fiduciaries to appropriate new corporate business prospects for themselves. See DEL. CodE ANN. tit. 8, § 122(17) (allowing corporation to renounce under certain circumstances any interest of corporation in certain business opportunities). Regarding this change in law and its effect, see Gabriel Rauterberg \& Eric Talley, Contracting out of the Fiduciary Duty of Loyalty: An Empirical Analysis of Corporate Opportunity Waivers, 117 CoLum. L. Rev. 1075, 1077-78 (2017).

156 Bebchuk \& Hamdani, supra note 154, at 496 n.16.

157 See Lyman P.Q. Johnson, Corporate Officers and the Business Judgment Rule, 60 Bus. LAW. 439, 455 (2005).

${ }^{158} I d$. (providing policy rationales for BJR, including "encouraging directors to serve and take risks").

159 See id. (arguing against broadening application of BJR).

160 Regarding the significant role of criminal and administrative law alongside civil liability in deterring corporate officers, see $i d$. at 469. 
risk and legal risk, sanctioning the former and shunning the other, we argue that the law should take a more nuanced and variegated approach to legal risk. Consistent with this insight, in the next Part, we develop a new legal framework that strikes a better balance between business risk and legal risk without unduly undermining respect for the law.

\section{A New Framework For Evaluating Legal Risk}

In the two previous Parts, we discussed and critically evaluated existing justifications for the differential doctrinal treatment of business risk and legal risk. Furthermore, we introduced a new justification-the lack of board oversight of legal risk-and assessed its merits and limitations. Although the justifications we discussed, including our own, clearly have explanatory power, we are of the opinion that none of them can fully justify the sharp distinction between the two forms or risk that informs legal policy in the corporate domain. Therefore, in this Part, we embark on the task of designing a new, superior framework for addressing legal risk.

The sharp distinction between business risk and legal risk arises from current doctrine, which classifies every legal violation as a breach of the fiduciary's duty of loyalty. ${ }^{161}$ As a result, directors and officers are fully exposed to civil and criminal liability when legal risks materialize. ${ }^{162}$ At the same time, the law provides directors and officers with a panoply of protections against liability for harms resulting when business risks materialize. ${ }^{163}$ As we explained, this

${ }^{161}$ It is questionable whether the duty to obey the law derives from an independent fiduciary duty of good faith, or whether it is nested under the fiduciary duty of loyalty. This is mostly a semantic question that does not have much substantive impact. See Eisenberg, supra note 25, at 74-75 (examining history of fiduciary duty of good faith and why it remains important); Griffith, supra note 25, at 6,34 (analyzing principle of good faith in Delaware jurisprudence and arguing that good faith is more of a "rhetorical device" than "substantive standard"); Sale, supra note 25, at 463-95 (looking at key case law regarding good faith in Delaware and ending with definition of the principle); Strine et al., supra note 25, at 633-40 (focusing on role of good faith within corporate law to clarify inquiry into whether good faith is functionally separate or part of duty of loyalty); Julian Velasco, How Many Fiduciary Duties Are There in Corporate Law?, 83 S. CAL. L. Rev. 1231, 1234 (2010).

162 Del. Code AnN. tit. 8, § 102(b)(7) (2022).

163 See Miller v. AT\&T, 507 F.2d 759, 763 (3d Cir. 1974) (allowing stockholders' breach of fiduciary duty complaint against corporation and its directors to go forward); see also Roth v. Robertson, 64 Misc. 343, 351 (N.Y. Sup. Ct. 1909) (imposing liability on corporate managers for bribe paid in order that amusement park company would be able to operate on Sundays, despite Sunday closing laws, and thus maximizing its profits). Regarding the irrelevance of the BJR to legal violations, see Stephen M. Bainbridge, The Business Judgment Rule as Abstention Doctrine, 57 VAND. L. REV. 83, 97-98 (2004) (citing and analyzing case in which court hypothesized legitimate business judgments for conduct at issue but did not decide whether they would be correct); Patrick J. Ryan, Strange Bedfellows: Corporate Fiduciaries and the General Law Compliance Obligation in Section 2.01(a) of the American 
doctrinal wedge causes a gap between business risk and legal risk, which works to the detriment of shareholders. The principal lesson of our analysis is not that the distinction between business risk and legal risk should be abolished altogether, but rather that the doctrine that applies to legal risk ought to be reassessed and refined. In light of this conclusion, we construct a wholly new regime with respect to legal risk that distinguishes among various legal risks based on two parameters: (1) whether the relevant risk involves a potential violation of a criminal prohibition or an administrative norm and (2) the intensity of the risk, represented by its probability of materializing.

\section{A. Criminal Violations $v$. Regulatory Infractions}

The first parameter we employ in designing our new framework to legal risk concerns the character of the legal risk. In this respect, we suggest a distinction between risks that may lead to criminal violations and risks that may result in regulatory infractions. ${ }^{164}$ While both are obviously prohibited by the law, they vary in degree of severity. Criminal violations are considered more severe and morally objectionable than regulatory infractions. As criminal law scholars have noted, the distinction between criminal violations and regulatory infractions largely tracks the philosophical mapping of legal violations in two categories: mala in se and mala prohibita. ${ }^{165}$ A mala in se prohibition is a prohibition on an activity that is morally wrong, independent of the fact that it is legally prohibited, for example, robbery or murder. ${ }^{166}$ Mala prohibita are prohibitions on activities that are not morally repugnant independent of the law. ${ }^{167}$ Rather,

Law Institute's Principles of Corporate Governance, 66 WASH. L. REV. 413, 448 (1991) (noting how fiduciary doctrine does not automatically apply BJR to illegal managerial acts).

164 For a similar distinction, see Bainbridge et al., supra note 16, at 595-97 (detailing two convergent principles: duty of good faith and duty to monitor).

165 See Stuart P. Green, Why It's a Crime to Tear the Tag off a Mattress: Overcriminalization and the Moral Content of Regulatory Offenses, 46 EMORY L.J. 1533, 1560-61 (1997) (examining mala prohibita in context of economic and financial crimes); see also Mireille Hildebrandt, Justice and Police: Regulatory Offenses and the Criminal Law, 12 NEW CRIM. L. REV. 43, 45 (2009) (describing how scope of criminal law is affected by designation as either malum in se or malum prohibita offense). Regarding the distinction in criminal law, see generally The Distinction Between Mala Prohibita and Mala in se in Criminal Law, 30 Colum. L. Rev. 74 (1930). Regarding the ramifications of the distinction on moral culpability, see Michael L. Travers, Mistake of Law in Mala Prohibita Crimes, 62 U. CHI. L. ReV. 1301, 1322-24 (1995). Regarding the correlation between regulatory infractions and criminal violation and the mala in se and mala prohibita distinction, see $i d$. at 1301-31.

166 See generally R.A. Duff, Crime, Prohibition, and Punishment, 19 J. APPLIED PhiL. 98 (2002) (discussing relationship between mala in se, mala prohibita, regulation, and prohibition); Green, supra note 165, at 1570-74 (comparing and contrasting meaning and effect of mala in se and mala prohibita).

167 See Duff, supra note 166, at 98 (defining mala prohibita as crimes that involve conduct not wrongful independent of the law); Green, supra note 165, at 1570 (defining first uses of 
the wrongfulness of these prohibitions stems from the fact that the law bans them. 168 Speed limits and disclosure requirements are examples of mala prohibita.

We argue that the distinction between business risks and legal risks should apply with more force to violations of mala in se prohibitions. Corporate fiduciaries should do their utmost to avoid morally repugnant actions and omissions and should not expose their corporations to the risk of violating such prohibitions. At the same time, the law should be more forgiving of risk-taking in the realm of mala prohibita. Here, corporate fiduciaries should be given more leeway, though not a carte blanche, in deciding whether to expose the corporation to the risk of violating a mala prohibita prohibition. Our proposed distinction not only tracks common moral precepts but may also be justified on informational grounds. Mala in se prohibitions that form the core of our criminal law system are readily ascertainable for the most part. ${ }^{169}$ Moreover, the twin bedrock principles of criminal law-legality and lenity-require criminal prohibitions to be clear and unambiguous. ${ }^{170}$ Relatedly, criminal prohibitions are subject to restrictive interpretation and in cases of doubt ought to be construed in favor of the defendant. ${ }^{171}$ This interpretive principle further helps dispel the uncertainty actors face.

Consequently, directors and officers need not engage in complex interpretative challenges when faced with mala in se prohibitions. ${ }^{172}$ The same

mala prohibita as crimes that were wrong because civil authorities or positive law said they were wrong).

168 See Duff, supra note 166 , at 98.

169 See, e.g., Green, supra note 165 , at 1570.

170 See Babbitt v. Sweet Home Chapter of Cmtys. for a Great Or., 515 U.S. 687, 704 n.18 (1995) (describing rule of lenity as providing "fair warning" of legal consequences and representing that legislatures are in charge of defining crimes); United States v. Lanier, 520 U.S. 259, 265 n.5, 266 (1997) (explaining fair warning requirement, which leads to vagueness doctrine, rule of lenity, and prohibition of new interpretations of criminal statutes to unprecedented conduct under due process); Lawrence M. Solan, Law, Language, and Lenity, 40 WM. \& MARY L. Rev. 57, 58 (1998) (stating that rule of lenity is intended "to provide adequate notice to defendants (due process), and to reinforce the notion that only the legislature has the power to define what conduct is criminal and what conduct is not (separation of powers)"); see also John Calvin Jeffries, Jr., Legality, Vagueness, and the Construction of Penal Statutes, 71 VA. L. REv. 189, 219-20 (1985) (supporting narrower use of principle of lenity). For a general discussion regarding judges' interpretations of penal statutes, see Livingston Hall, Strict or Liberal Construction of Penal Statutes, 48 HARV. L. REV. 748, 756-62 (1935).

171 See Zachary Price, The Rule of Lenity as a Rule of Structure, 72 FORDHAM L. REV. 885, 909 (2004) (rationalizing rule of lenity on grounds that criminal penalties are especially serious and represent society's moral disapproval); Solan, supra note 170, at 58 (defining rule of lenity as strict construction against government or parties bringing suit and in favor of adverse party potentially subject to penalties).

172 Susan Dimock, Contractarian Criminal Law Theory and Mala Prohibita Offences, in Criminalization: The Political Morality of the Criminal Law 151, 152 (R.A. Duff et 
is not true for mala prohibita norms. Many of these norms originate in administrative laws, regulations, and rulings. The multiple sources of mala prohibita norms make it more difficult for corporate actors to ascertain that they identified all the relevant norms that apply to their decisions. ${ }^{173}$ Moreover, mala prohibita norms are less accessible to laypersons and even people trained in the law. ${ }^{174}$ For instance, the contours of many tax law provisions and regulations cannot be read with pinpoint precision and thus it is nearly impossible to verify in advance whether a certain course of action constitutes a tax violation. ${ }^{175}$ Finally, the principle of lenity does not ordinarily extend to administrative prohibitions. ${ }^{176}$ Hence, these prohibitions need not be drafted with the same level of clarity, as criminal law prohibitions.

\section{B. Likelihood of the Risk}

The second dimension along which we propose classifying risks concerns their likelihood, or probability, of occurring. Specifically, we argue that legal risks should be broken down into three broad levels: remote, reasonable, and substantial. This tripartite distinction has not been devised by us, but is taken from the GAAP that have been adopted by the SEC. ${ }^{177}$ The terms "remote," "reasonable," and "probable" under the GAAP denote levels of probability that a risk will transpire and inflict a loss on the corporation. ${ }^{178}$ These three categories are utilized for determining whether a potential loss ought to be disclosed and reported under securities regulations. ${ }^{179}$ The probability thresholds employed by the GAAP are arrayed on a continuum, ranging from

al. eds., 2014) ("When non-experts think about criminal law, the specific examples of criminal offences they most readily identify are undoubtedly mala in se: murder, rape, robbery, kidnapping, and the like.").

173 Id. at 179.

${ }^{174}$ Id. at 151-52; Travers, supra note 165, at 1301-02 (advocating for adoption of mistake of law as viable defense in cases involving mala prohibita offenses that require mens rea level of recklessness or higher).

175 See Travers, supra note 165, at 1304 ("Congress, the Court reasoned, did not intend that a person should become a criminal by reason of a bona fide misunderstanding of the tax laws, especially in light of their complexity.").

176 See Babbitt v. Sweet Home Chapter of Cmtys. for a Greater Or., 515 U.S. 687, 704 n.18 (1995) ("We have never suggested that the rule of lenity should provide the standard for reviewing facial challenges to administrative regulations whenever the governing statute authorizes criminal enforcement."); see also Julian R. Murphy, Lenity and the Constitution: Could Congress Abrogate the Rule of Lenity?, 56 HARV. J. ON LEGIS. 423, 448 (2019).

177 SEC's Focus on Compliance with Loss Contingency Disclosures, DeloITTE: PERSPECTIVES, https://www2.deloitte.com/us/en/pages/audit/articles/financial-reporting-lert11-1.html [https://perma.cc/3LER-JJ49] (last visited Sept. 15, 2022) (reporting on new SEC reporting alert but noting that it does not amend existing GAAP requirements).

${ }^{178} I d$.

179 FIn. ACCT. STANDARDS BD., supra note 17, at 51. 
"remote" to "reasonable"to "probable." 180 Although the GAAP do not provide precise numerical values for each category, in practice, a "remote" risk is one whose probability of occurring and inflicting a loss on the corporation is 0.1 or lower, a "reasonably possible" risk is associated with a probability that is higher than 0.1 but lower than 0.7 , and a "probable" risk is one whose likelihood of eventuating is 0.7 or higher. ${ }^{181}$ We do introduce one important modification into the GAAP. Because we believe that any risk with a likelihood of occurring higher than 0.5 is not reasonable, for the purpose of our analysis we define a reasonable risk as one with a probability of occurring between 0.1 and 0.5 , and a probable risk as one that that falls in the range of 0.5 to 1 .

Combining the two proposed distinctions yields six classes of legal risk: (a) remote administrative risk, (b) remote criminal risk, (c) reasonable administrative risk, (d) reasonable criminal risk, (e) probable administrative risk, and (f) probable criminal risk. Having devised taxonomy of legal risks and a matrix for classifying them, our next task is to tailor a unique liability regime for each risk category. It is to this task that we now turn.

\section{New Liability Regimes}

It should be noted at the outset that we do not seek to modify the law as it applies to the liability of corporations - only as it applies to the personal liability of directors and officers. In the latter context, our proposal harnesses liability regimes that should be familiar to our readers, such as the BJR and enhanced scrutiny. The use of familiar liability forms reduces the transition costs associated with our proposal by allowing judges to employ legal machinery with which they are familiar. The use of these forms also lowers information costs for directors, officers, and legal counsel.

\section{Remote Administrative Risk}

Our first category, remote administrative risk, applies to decisions giving rise to a relatively low risk of a violation of an administrative norm that is not part of the penal code. The violations that fall into this category are the least severe and morally repugnant from a societal standpoint, and the probability of their occurrence is low. Accordingly, we propose that the liability of directors and officers for assuming remote risks with respect to regulations be governed by the BJR. The BJR immunizes business decisions from judicial review if they are informed, adopted in good faith, and without a conflict of interest. ${ }^{182}$ When these

${ }^{180} \mathrm{Id}$. at 10 (mandating disclosure about contingency if possibility is reasonable, or more than remote, for example).

181 Deloitte, Roadmap: Contingencies, Loss Recoveries, and Guarantees 20-22 (2021) (denoting practical quantitative thresholds for three categories).

182 See, e.g., Polacheck v. Michiwaukee Golf Club Land Co., 223 N.W. 233, 234 (Wis. 1929) ("Courts will not interfere in the internal management of corporate affairs, in the absence of allegations clearly disclosing abuse of power by corporate officers, bad faith, or willful abuse of discretion or positive fraud.”); Figge v. Bergenthal, 109 N.W. 581, 589 (Wis. 
conditions are obtained, courts will not review the substance of the decision and will not subject directors and officers to personal liability, even if it turns out that the decision occasioned a significant loss for the firm. ${ }^{183}$ The BJR has been adopted to give managers and directors leeway in making business decisions. ${ }^{184}$ Because business decisions often implicate a certain level of legal risk, we opine that the BJR should also cover decisions involving low probability legal risks that may lead to relatively low levels of social harm that are inexorably intertwined with business decisions.

That said, because we view legal risk more harshly than pure business risk, we pose an additional precondition that must be satisfied for the BJR to apply. To qualify for the protection of the BJR, we would require directors and officers to satisfy one additional requirement: that they acted on the advice of a competent legal expert who certified that the risk implicated was remote and regulatory in nature. We would also require the legal counsel of the board to review the opinion and approve of it.

If these requirements are met, a court will only examine the procedural elements of the decision. Inter alia, the court will query whether the legal expert had sufficient expertise in the relevant legal field, whether she was independent, and whether she was provided with all of the relevant information. If the answers to all these questions are in the affirmative, and the legal expert classified the potential risk generated by the decision as a remote administrative risk, fiduciaries would be shielded from any personal liability even if, ex post, a court determines that their decision violated an administrative norm. As an illustration of our proposed regime, consider the following example. Assume a company, Smart Micro Processors Inc. ("SMP”), experienced to a cyberattack. The attack targeted SMP's intellectual property. The data was stolen but not corrupted. Thereafter, SMP's executives hold a conference call with the board to discuss whether the attack must be reported. The CEO assesses that the cyberattack will probbaly not cause a severe harm because the company does not face serious competition given its unique technology. She also estimates that if the attack is reported, it will result in serious reputational harm to the company, causing the shares to drop by $20 \%$ without any substantive reason. The board decides not to disclose. ${ }^{185}$ Under our proposed regime, if the board's decision had been based on an expert opinion that non-disclosure exposes the company to a remote risk

1907); Theis v. Durr, 104 N.W. 985, 987-88 (Wis. 1905) (determining that court cannot regulate corporate conduct without bad faith).

183 See Polacheck, 223 N.W. at 234.

184 See Yates v. Holt-Smith, 768 N.W.2d 213, 219 (Wis. Ct. App. 2009) (“The business judgment rule is designed to limit judicial involvement in business decision-making so long as a minimum level of care is exercised in arriving at the decision.").

185 Such a decision is not unprecedented. While studies estimate that around $90 \%$ of companies are targeted by cyberattack, nearly $40 \%$ of public companies have not mentioned cybersecurity issues in their SEC filings. Sam Young, Note, Contemplating Corporate Disclosure Obligations Arising from Cybersecurity Breaches, 38 J. CoRP. L. 659, 667 (2013). 
of a regulatory infraction, the officers and directors would be protected by the BJR.

\section{Remote Criminal Risk}

Our second category, remote criminal risk, covers policies and decisions that involve a relatively low risk of breaking the law, yet the relevant legal norm is a criminal prohibition. As we explained, criminal prohibitions should be given special deference and potential violations of criminal norms should be treated most severely. For this reason, we would only allow corporate directors and officers to consider courses of action that might give rise to a violation of a criminal prohibition if and only if the probability of the violation is remote and the company is in possession of either a written expert opinion or a preruling letter from an administrative agency stating the planned course of action is legal. ${ }^{186}$

If these twin conditions are satsfied, we propose that the liability of the directors and officers responsible for such a decision implicating a remote criminal risk would be evaluated under the enhanced BJR - sometimes called enhanced scrutiny-standard of review. Under this standard, directors and officers would be sheltered from liability if they can prove that their actions were reasonable and that the expected loss was proportionate to the expected benefit. ${ }^{187}$

To satisfy the first prong of the enhanced scrutiny test - that the contested decision was reasonable-directors and officers would need to produce either a written expert opinion stating that the risk involved in the decision is remote or an administrative preruling to this effect. ${ }^{188}$ As before, we would require the legal opinion to be authored by a renowned legal expert whose reputation in the relevant area is indisputable. Here too, the opinion ought to be reviewed and endorsed by a firm's legal counsel before management and the board rely on it. Alternatively, the directors and officers can seek a preruling from the relevant administrative agency prior to proceeding with their plan. An administrative preruling would almost invariably satisfy the reasonableness requirement of the enhanced scrutiny test. We are even willing to adopt a rebuttable presumption to this effect. That said, administrative prerulings are rather rare and difficult to

${ }^{186}$ Example of administrative prerulings are the issuance of private letter rulings by the Internal Revenue Service ("IRS"), no-action letters by the SEC, standard interpretations by the Occupational Safety and Health Administration, and business review letters by the Department of Justice Antitrust Division. For a discussion of administrative agency preruling activities, see Yehonatan Givati, Game Theory and the Structure of Administrative Law, 81 U. CHI. L. REv. 481, 484-91 (2014) (using game theory framework to explain how agencies might choose between policymaking instruments, including preruling).

187 See Unocal Corp. v. Mesa Petroleum Co., 493 A.2d 946, 954-55 (Del. 1985).

188 See id. at 955. 
secure. ${ }^{189}$ As Professor Yehonatan Givati noted, even when prerulings can be obtained in principle, the attendant process is both expensive and time consuming. ${ }^{190}$ Hence, prerulings do not offer a viable solution to firms' need to move expeditiously.

The second prong of the enhanced scrutiny test-proportionality between the expected loss and the expected benefit-is designed to ensure that management's plan or course of action was supposed to result in a profit of the shareholders. ${ }^{191}$ This condition provides an important check on firms' management as it forces them to verify that the expected gains from their actions outweigh the expected costs. ${ }^{192}$ If the expected costs are high, the expected gains must be even higher. The proportionality requirement thus ensures internalization of the potential costs of firms' actions on the public. ${ }^{193}$ In keeping with this important principle, we would require management and the board to adduce evidence demonstrating that the potential loss they envisioned bore proportionality to the possible benefit they foresaw.

To illustrate the remote criminal risk category, consider the following example. The firm Antica Zeneca developed a very effective flu vaccine, which received Food and Drug Administration ("FDA") approval. The company has found evidence that the vaccine may also have limited efficacy against COVID19, but it never applied for FDA approval for that use. The law permits use of an FDA-approved drug for addressing a different health issue than that for which it was approved to treat, but the company is not allowed to promote and market the drug for that non-approved use. ${ }^{194}$ Due to the enormous demand for COVID19 vaccines, the executives of Antica Zeneca decide to invite hundreds of doctors to an enormous global conference on the anti-COVID-19 effect of its vaccine, based on their assessment that the event would dramatically increase the usage of the vaccine and generate billions of dollars in additional revenues. When the executives present the plan to the board, the board fears that if the use

189 See, e.g., Yehonatan Givati, Resolving Legal Uncertainty: The Unfulfilled Promise of Advance Tax Rulings, 29 VA. TAX REV. 137, 173 (2009).

${ }^{190} \mathrm{Id}$.

191 See Cede \& Co. v. Technicolor, Inc., 634 A.2d 345, 361 (Del. 1993) (“"[T]he directors have the burden of establishing that the price offered was the highest value reasonably available under the circumstances."); Unocal, 493 A.2d at 954-55.

192 See Cede \& Co., 634 A.2d at 361.

193 Id.

194 The legal constraint on the promotion of nonlabeled drugs mainly stems from the labeling requirement prescribed by law that the instructions on the label must be sufficient to allow practitioners to "use the drug safely and for the purposes for which it is intended." 21 C.F.R. $\$ 201.100$ (c)(1) (2022). Thus, if the manufacturer intends doctors to prescribe the drug for a particular use for which the label does not provide adequate directions, it violates the legal labeling requirement. According to FDA regulations, any promotional statement of the drug maker for the off-labeled use is evidence for its intended usage. See 21 C.F.R. $\S 201.128$ (equating "intended uses" of drug to labeler's "objective intent"); see also Kathryn Bi, What Is “False or Misleading” Off-Label Promotion?, 82 U. CHI.L.REV. 975, 981 (2015). 
of the vaccine would spread significantly, the FDA and Department of Justice ("DOJ") may view the conference as an act of illegal promotion of a drug for off-label purposes. Yet, this is a very remote concern because the organization of a scientific conference probably does not come within the plain meaning of the words "advertising matter, or oral or written statements." 195 The organization of a conference does not seem to constitute an act of "advertising" or a "statement" of the company. The company estimates that there is only 0.1 probability that the conference would be deemed illegal, in which case a penalty of $\$ 100$ million dollars would be assessed against it. Recall that the expected benefits from the conference run in the billions. Without our proposal, it is most likely that the board would not authorize the conference, due to the remote chance it will face personal liability. ${ }^{196}$ Under our novel liability regime, the board would ask for an opinion from a legal expert and if she similarly assesses the probability of the risk at 0.1 or lower, as she should, the board would most likely approve the conference. If subsequent derivative actions are commenced against the executives and board members of the company, they would benefit from the legal defense of the enhanced BJR and should be able to easily demonstrate that their decision was reasonable, and that the expected risk was proportionate to the expected benefit. Our proposed regime would most likely alter the decision of the board and thereby increase the gains to shareholders.

\section{Reasonable Administrative Risk}

Our third category, reasonable administrative risk, covers decisions and policies that may result in a regulatory infraction with a probability of 0.1 to 0.5 . Regulatory infractions are considered less severe than criminal violations. Yet, in this case, the risk level is substantial, and the law should reflect this fact. Accordingly, we propose that the personal liability of directors and officers for decisions involving a reasonable risk of a regulatory infraction be governed by a liability regime that falls somewhere in between the enhanced scrutiny and entire fairness tests. ${ }^{197}$ The enhanced scrutiny test places the burden on directors and officers to show that their decision was reasonable and that the expected benefits exceeded the expected costs. ${ }^{198}$ If management and the board meet this

19521 C.F.R. $\$ 201.128$

196 See Del. Code AnN. tit. 8, § 102(b)(7) (2022) (prohibiting limitations of directors' personal liability for violations of duty of loyalty).

197 A model for such midlevel liability regime is the one adopted by the Delaware Chancery Court in In re Southern Peru Copper Corp. Shareholder Derivative Litigation, 52 A.3d 761 (Del. Ch. 2011). The court had reviewed the special committee's approval of a transaction in which a firm purchases a private firm from its controlling shareholder. $I d$. at 765. Unlike the subsequent decision in Kahn v. $M \& F$ Worldwide Corp., 88 A.3d 635, 654 (Del. 2014), overruled by Flood v. Synutra, Inc., 195 A.3d 754 (Del. 2018), which shielded fiduciaries from liability by finding the structure and procedure adequate, Southern Peru examined whether the dynamic reflected an independent decision.

198 See Unocal Corp. v. Mesa Petroleum Co., 493 A.2d 946, 955 (Del. 1985). 
burden, they will be entitled to the protection of the BJR and the court will not substantially review their decision. ${ }^{199}$ Under the entire fairness test, the most stringent review standard in corporate law, directors and officers must show that both the process that led to the decision and the decision itself were optimal. ${ }^{200}$ Unlike the enhanced scrutiny standard, the entire fairness test involves substantive review of a firm's decisions. ${ }^{201}$

Our suggested regime is a hybrid of the two tests. Under it, directors and officers who assumed a reasonable regulatory risk would be sheltered from liability if they prove that the decision was reasonable, and the foreseen benefits were greater than the expected costs. In addition, management and the board would have to show that they relied on an expert opinion or an administrative preruling that it is more likely than not that their decision would not be considered a regulatory infraction, meaning the risk is lower than 0.5 .

Even so, the judicial review in this case would not be purely procedural. Rather, it would incorporate substantive oversight of the legal opinion on which management and the board relied, as well as careful examination of the underlying process that led to the decision. ${ }^{202}$ Although the scrutiny we propose does not amount to a entire fairness review, it empowers the court to secondguess management and the board.

The regime we envision is illustrated via the following example. ${ }^{203}$ Assume that Wonsanto Inc. is a public company. Wonsanto's marquee product, Woundup, is the bestselling herbicide on the market. To boost the sales of Woundup, the company offered millions of dollars in rebates to hundreds of thousands of consumers. Due to an outmoded accounting system, Wonsanto could not accurately account for the amounts it offered in rebates, which prompted a concern of a possible violation of the SEC's accounting rules and misstatement of profits. To extricate itself from its predicament, Wonsanto decided to report the same liability for rebates as in the previous quarter, even though it knew that the figure was much higher. At the company's request, an

\footnotetext{
${ }^{199} I d$.

200 See Weinberger v. UOP, Inc., 457 A.2d 701, 710 (Del. 1983).

201 See id. at 711 ("All aspects of the issue must be examined as a whole since the question is one of entire fairness.").

202 See S. Peru, 52 A.3d at 787 (regarding Southern Peru standard of judicial review). Even though a more lenient standard of review has been adopted with respect to the review of approvals of independent committees subsequently in the Kahn, 88 A.3d at 644, decision, the probability of illegality justifies the harsher Southern Peru standard of review. The court will not only examine the formal independence of the legal expert, but also conduct a substantive review of the decision in order to examine whether it reflects thorough independent judgment.

203 The example was inspired by an administrative enforcement case that was brought by the SEC against the Monsanto company and was settled in 2016. See Press Release, Sec. \& Exch. Comm'n, Montsanto Paying \$80 Million Penalty for Accounting Violations (Feb. 9, 2016), https://www.sec.gov/news/pressrelease/2016-25.html [https://perma.cc/8VHWYKZL]. We changed many of the underlying facts.
} 
external legal expert delivered a written opinion to the company, stating that the measure likely complies with SEC regulations and that the level of risk involved is lower than 0.5. The plan was carried out and Wonsanto's shares went up. Subsequently, when a journalist reported the story, the shares plummeted and a group of shareholders brought a class action lawsuit against the company and its directors and officers, claiming that they knowingly inflated the company's profits.

In our example, Wonsanto's directors and officers relied on an expert opinion they received from a renowned accounting firm. Yet, to avoid liability, they will also bear the burden of showing that their actions were reasonable and that the expected benefits therefrom exceeded the foreseeable costs. That is, the expected reputational losses that were averted because of the decision were greater than the expected administrative fine that might have been levied on the firm. All aspects of the decision, including the quality of the expert report, would be subject to substantive review. If a court finds that one of the conditions was not met, it could impose personal liability on the directors and officers.

\section{Reasonable Criminal Risk}

Our fourth category, reasonable criminal risk, covers decisions that may lead to the imposition of criminal liability on a firm with a probability of 0.1 to 0.5 . Because of the special gravity society attributes to criminal violations and the fact that these kinds of cases involve a nonnegligible probability of violation, we believe that an expert legal opinion should not provide directors and officers protection against derivative actions. If a court finds ex post that a criminal legal norm was violated, directors and officers would be exposed to personal liability for violating their duty of loyalty, even if their decision was based on an expert legal opinion that purports to legitimize the decision.

To illustrate the implications of our proposed liability regime in the case of reasonable criminal risk, consider the case of RR Co., a U.S. multi-national corporation that constructs railroads. It cooperates with local companies in a foreign country to construct a new railroad which requires the approval of the zoning committee for national projects. RR Co. will receive $\$ 500$ million and make a net profit of $\$ 200$ million if the project is approved. The chairman of the committee approaches the CEO of RR Co., informing her that there seems to be a majority for approving the project, but he cannot know when the decision will be made. Following the conversation, the CEO suggests to the board that RR should send an agent to the chairman who will provide him $\$ 50,000$ in cash and promises to provide an additional $\$ 50,000$ if a decision is reached within two months. Both the board and the CEO understand that this decision involves a serious legal risk of violating the FCPA, which prohibits U.S. businesses from securing contracts by bribing foreign officials. ${ }^{204}$ At the same time, the FCPA permits payments to officials that are not intended for obtaining business, but

${ }^{204} 15$ U.S.C. $§ 78 \mathrm{dd}-1$ (prohibiting bribery of any foreign official to influence or induce them). 
are solely for expediting decisions. ${ }^{205}$ The board members intend the payment to expedite the decision but understand that prosecutors and judges may view this payment as intended to obtain business, as the payments preceded the decision and the informal update of the chairman may be construed as an invitation for a bribe.

Under our proposed liability regime, an expert legal opinion that sanctions the actions of RR Co. would not provide shelter to its management and board. The legal expert must be aware of the significant legal risk implicated in this case and rate it as a reasonable legal risk. Accordingly, fiduciaries will be exposed to personal liability due to their violation of the duty of loyalty in such cases. As a result, it is most likely that fiduciaries will refrain from taking such legal risks.

It should be noted that even if a company somehow succeeds in obtaining a legal opinion that misrepresents the risk as remote, it will not help its management and board. Recall that under our proposal, in cases of criminal violations, a court is expected to engage in a substantive review of the expert opinion. Consequently, it would reject the risk rating of the expert and proceed to impose personal liability on the board and management, and when appropriate, on the legal expert as well. Hence, our system cannot be easily manipulated. The decisions of the directors and officers and the informational basis on which they were made would always be subject to ex post judicial scrutiny.

\section{Probable Administrative Risk}

The fifth category, probable administrative risk, applies to decisions which will likely lead the firm to violate an administrative norm. In such cases, the high risk of a violation, 0.5 or higher, will eliminate any legal protection to the fiduciaries involved, even though the administrative violations are considered less severe than criminal ones. Accordingly, fiduciaries would be exposed to personal liability for violating their duty of loyalty if the risk materializes and a court finds that firm has violated an administrative norm. No expert opinion would help the board and management in this case.

The operation of our proposed regime is illustrated by the following example. Assume that ZeroTax Inc. is a holding company that owns U.S. and foreign subsidiaries. ZeroTax Inc., wishes to minimize its tax liability by allocating as many costs as possible to its U.S. subsidiary, a practice known as "transfer pricing." ${ }^{206}$ An aggressive transfer pricing policy may be deemed as tax evasion

205 See SEC Off. of Inv. Educ. \& Advoc., Investor Bulletin: The Foreign Corrupt Practices ACt - Prohibition of the Payment of Bribes to Foreign OfFicials 2 (2011).

${ }^{206}$ See PwC, United States, in International Transfer Pricing 2013/14, at 816, 834 (2013). 
punishable by administrative fines. ${ }^{207}$ Aware of this risk, yet determined not to pay taxes, ZeroTax Inc.'s management seeks an expert opinion letter from a tax law professor in support of its plan. Given the aggressive nature of ZeroTax Inc.'s strategy, no letter would help fend off the personal liability of the directors and officers. ${ }^{208}$ Because in ZeroTax Inc.'s case the end (not paying taxes) justifies the means, it is willing to assume a probable risk of breaking the law. Given the probability of the risk, the management and board can seek no safe harbor from personal liability. Obviously, no expert letter should change the analysis and if the company somehow succeeds in convincing an expert to misstate the probability of the risk involved, a court should reject the expert's analysis, set the risk correctly, and proceed to impose liability on the directors and officers.

\section{Probable Criminal Risk}

The sixth category, probable criminal risk, covers decisions that are likely to lead the firm to violate a criminal legal prohibition. As we already explained, we believe there should be no protection for directors or officers for decisions involving reasonable criminal risk. A fortiori, directors and officers should be granted no protection in cases of probable criminal risk. Stated affirmatively, directors and officers would be held personally responsible for losses resulting from criminal violations where the risk of loss was probable. Accordingly, if a corporate executive or the board is of the opinion, based on her own understanding or an expert opinion, that a certain cause of action involves a probable criminal violation, she should resolutely oppose it or face the consequences.

The following example provides an illustration of how board members ought to act when they become aware of an activity that involves probable criminal risk. Imagine a chemical company, Chem Co., that discharges waste into the city's sewage system. The Clean Water Act prohibits discharging pollutants into the waters of the United States from any point source ${ }^{209}$ without a permit issued under the National Pollutant Discharge Elimination System ("NPDES"). ${ }^{210}$ Under the NPDES, Publicly Owned Treatment Works ("POTW") determine pretreatment requirements for industrial users. ${ }^{211}$ Chem Co.'s permit provides that the level of phosphorous in its wastewater cannot exceed $10 \mathrm{mg} / \mathrm{L}$. Chem Co. decides to use the maximal level of phosphorous stipulated in its permit in

207 See id. ("The US Competent Authority has stated that transfer pricing penalties will not be subject to negotiation with tax treaty partners in connection with efforts to avoid double taxation.").

208 See 26 C.F.R. $\$ 601.201$ (2021) (defining and listing requirements for rulings, determinations letters, and other matters).

20933 U.S.C. $\S 1251$.

21033 U.S.C. $\$ \S 1311(\mathrm{a}), 1342$.

21133 U.S.C. $\S 1342$ (b)(2)(B)(8); 40 C.F.R. $§ 403.8$ (2020) (requiring POTWs to develop pretreatment program). 
its wastewater. The company's compliance officer informed the board that, as a precautionary measure, she decided to increase discharges of clean water during the periods of municipal inspections to ensure that the company does not exceed its phosphorous discharge level under the permit. The board expressed concern that the practice might constitute a criminal offense under the Clean Water Act, ${ }^{212}$ but the compliance officer emphasized that the company's practice would not count as an intentional violation because it is most likely that the phosphorous discharges do not exceed the permitted level. The compliance officer further noted that if the company added clean water to its discharges all year round, there would be no violation at all. Assume that the board remains skeptical and requests an opinion from a legal expert, who opines that the spilling of extra water is likely to be interpreted as an indication that the company knew that it violated the terms of the permit and, therefore, there is a probability of over 0.8 that it will be criminally indicted. Under our proposed regime, the board must advise that the practice of adding clean water to the wastewater in order to depress the level of phosphorous be discontinued immediately and find another way to address the phosphorus problem.

\section{CONCLUSION}

In his bestselling book, Against the Gods: The Remarkable Story of Risk, Peter Bernstein argued that what separates modern times from past eras is the availability of tools to manage risk..$^{213}$ Although Bernstein does not address legal risk specifically and focuses on risk more generally, his book and its core thesis are very much in line with the general project of this Article. Our goal in this Article has been twofold. First, we set out to investigate the possible reasons for corporate law's disparate treatment of business risk and legal risk. While corporate law shelters directors and officers from personal liability for losses which resulted from materialized business risks, it exposes them to full civil and criminal liability for harms that result from legal risk-taking. ${ }^{214}$ This stark contrast between the law's approach to these two kinds of risk struck us, as well as other commentators, as a nontrivial puzzle. After all, legal risk cannot be completely avoided in the corporate world, and careful management of small legal risks can yield high returns for shareholders. ${ }^{215}$

In our attempt to explain the law's approach to legal risk, we critically reviewed all existing justifications for the current legal regime and ultimately found them unpersuasive. We, thus, proceeded to develop a novel justification that explains the law's uncompromising approach to legal risk in the corporate

\footnotetext{
212 See 33 U.S.C. $\$ 1319$ (c)(2)(A) (defining criminal penalties associated with knowing violations of certain sections, including prohibition on pollution).

213 Peter L. Bernstein, Against the Gods: The Remarkable Story of Risk 1-3 (1998).

214 See Del. Code Ann. tit. 8, § 102(b)(7) (2022); see also Aronson v. Lewis, 473 A.2d 805, 812 (Del. 1984), overruled by Brehm v. Eisner, 746 A.2d 244 (Del. 2000).

215 See discussion supra Part II.A.
} 
context. We argued that because of the exposure of board members to personal liability for losses resulting from legal risk, board members would veto all policies and decisions implicating even minimal legal risk. Aware of this disposition, managers - whose compensation is often tied to performance and are therefore more risk-seeking-would prefer not to raise policies and decisions that implicate legal risk to board discussion. This, however, works to the detriment of shareholders who are deprived of the protective mechanism of board oversight with respect to legal risk. Legal risks, in contrast to business risks, largely escape board scrutiny.

While the justification we developed has stronger explanatory power than prior justifications, we nonetheless felt that the current legal approach to legal risk is too extreme. This led us to the second, more significant contribution of the Article. We constructed a new comprehensive legal framework for evaluating decisions involving legal risk. Our thinking was motivated by the modern philosophy toward risk - that all risks can be managed. Consistent with this conviction, we divided legal risks into two categories of severity: risks involving criminal prohibitions and risks pertaining to non-criminal norms. We then further classified legal risk based on its probability of occurrence, differentiating among remote, reasonably possible, and probable risks. The combination of our two matrixes resulted in six different classes of legal risks. Finally, we designed a unique liability regime for each class of risk. The framework that we designed would allow corporate executives and directors to address low and reasonable levels of legal risk in a responsible way that would benefit shareholders, without eroding respect for law and morality. 